\title{
Combining Networks, Ambidexterity and Absorptive Capacity to Explain Commercialization of Innovations: A Theoretical Model from Review and Extension
}

\author{
Avimanyu Datta \\ Department of Management \& Quantitative Methods \\ College of Business, Illinois State University \\ Campus Box 5580, Normal, IL 61790-5580, USA \\ Tel: +1-309-438-5701Ｅ-mail: avimanyu.datta@gmail.com
}

Received: October 10, 2011

Accepted: October 28, 2011 Published: December 15, 2011

doi:10.5430/jms.v2n4p2

URL: http://dx.doi.org/10.5430/jms.v2n4p2

\begin{abstract}
From a thorough review of literature we investigate the key antecedents and mediators to commercialization of innovations. We posit that a firm's network, absorptive capacity and ambidexterity (ability to explore and exploit) each affect commercialization of Innovations. Further, we showed that networks are antecedents to absorptive capacity and ambidexterity, and absorptive capacity is an antecedent to ambidexterity. We integrate these concepts together and present an integrated theoretical model for further research.
\end{abstract}

Keywords: Commercialization of Innovations, Absorptive Capacity, Potential Absorptive Capacity, Realized Absorptive Capacity, Ambidexterity, Social Networks, Exploration, Exploitation, External Networks, Internal Networks.

\section{Introduction}

Successful commercialization of innovation (CI) is of strategic importance to (A. A. Nerkar, McGrath, \& MacMillan, 1996) to remain competitive (Nevens, Summe, \& Uttal, 1990), and is necessary to advance the economy at large. Further, it improves a firm's market penetration and dominance (and even help that firm to create a new market), which contributes to the attainment of sustained leadership and firm longevity. In addition, literature has shown that commercialization of innovations leads to higher firm performance (Ahuja, 2000a; Ahuja \& Katila, 2001; Ahuja \& Lampert, 2001; Tushman \& O'Reilly, 2002). The increased pace in innovating and commercializing not only helps the innovators to be successful but also raises the bar for competitors. While companies clearly try hard to launch new products into the market, few are successful. Why is it then, that some firms are much better commercializing innovations than others? This work seeks to answer this question.

Past literature has linked commercialization of Innovation with firm's capabilities (Damanpour, 1991; Dougerty \& Hardy, 1996; Grant, 1996; McGrath, Tsai, Venkataraman, \& MacMillan, 1996; Pennings \& Harianto, 1992; David J. Teece, Pisano, \& Shuen, 1997), human resource practices (A. A. Nerkar, et al., 1996; S. G. Scott \& Bruce, 1994), the nature of top management teams (Bantel \& Jackson, 1989; Howell \& Higgins, 1990), and the external environment within which the firm operates (Abrahamson \& Rosenkopf, 1993; Keats \& Hitt, 1988; Milliken, 1987; J. Wade, 1996; M. Wade \& Hulland, 2004). Much of the cited literature, however, treated innovation and its commercialization as the same construct, where commercialization in many cases was assumed. While we agree that innovation characteristics are a necessary component of future market success, innovation per se is not sufficient to ensure that success. Instead, innovations generally lead to market success through the process of commercialization (Drucker, 1985). We, therefore, focus our model on commercialization of innovation.

Ambidextrous organizations are those that are capable of exploiting their existing competencies while exploring new opportunities (Bodwell \& Chermack, 2009; Datta, 2011a, 2011b; Lubatkin, Simsek, \& Veiga, 2006; March, 1991; O'Reilly \& Tushman, 2007). A number of studies have posited that a balance between exploration and exploitation leads not only to organizational renewal but also helps firms to become more innovative resulting in longevity through commercialization of innovations that are radically different while not losing grip on incremental innovations (Tushman \& O’Reilly, 2002). 
Literature has also cited that an increasing a firm's absorptive capacity can lead to organizational renewal (Datta, 2011a, 2011b; Narasimhan, Rajiv, \& Dutta, 2006). Notwithstanding a few key works (Jansen, Vanden Bosch, \& Volberda, 2005a, 2005b, 2006), the literature on absorptive capacity has largely ignored the concept of ambidexterity. Successful are those firms that can continuously explore new technologies and markets, while maintaining their exploitive stance with existing markets and technologies (O’Reilly \& Tushman, 2004; Tushman \& O'Reilly, 1996a, 2002). Success at commercialization innovations entails a firm to be ambidextrous.

In addition, knowledge of emerging markets and technologies comes from networks external to the firm's boundaries (Ahuja, 2000a; Ahuja \& Katila, 2001; Ahuja \& Lampert, 2001; Phelps, 2003, 2010; Schilling \& Phelps, 2007). Despite the benefits, such networks may cripple a firm with information overload, and success often times lie in the firm's ability to develop and routinize information filters, internally (Simsek, 2009).

There has been efforts to link networks with CI (Ahuja \& Lampert, 2001), networks with ambidexterity (Birkinshaw \& Gibson, 2004; Simsek, 2009; Simsek, Heavey, Veiga, \& Souder, 2009; Tushman \& O'Reilly, 1996a) and networks with absorptive capacity (W. M. Cohen \& D. A. Levinthal, 1990; Lane, Koka, \& Pathak, 2006; Lane \& Lubatkin, 1998; Lane, Salk, \& Lyles, 2001; Todorova \& Durisin, 2007; Zahra \& George, 2002). We believe an integrative view will help us a more comprehensive understanding on the antecedents of commercialization of innovation and their interplay with each other. This is particularly important since there is a continued theoretical interest in CI whereby the assumptions and boundary conditions need to be assessed and the interplay between the antecedents and moderators need to be evaluated. Such an integrative view merges the gap between four constructs of interest: CI, networks, ACAP and ambidexterity) whereby research in each area can enrich themselves by incorporating concepts from each other. For instance, research on networks can see increase in absorptive capacity and attainment exploration of emerging markets and technologies as a positive outcome. Such an integrative view will also extend our understanding of knowledge transfer through integration of complimentary knowledge and technologies, especially absorptive capacity and relative absorptive (W. M. Cohen \& D. A. Levinthal, 1990; Lane \& Lubatkin, 1998) by means of networks and how that leads to success in commercialization of innovations.

Commercialization of Innovations (CI) is the dependent construct of this paper, and our discussions on the relationships between networks, ambidexterity and absorptive capacities helped us getting a more comprehensive view. However, we are not claiming that that the posited model is an all encompassing view of CI. Instead, it is a step toward generating an integrative view by integrating, synthesizing and expanding on the existing literature. In posing our model, we have assumed that the operating environment in terms of turbulence, complexity and dynamism (Dess \& Beard, 1984) remains constant. Further, in underscoring the relationship between external networks and absorptive capacity, we held internal networks constant, and vice versa.

The rest of this paper is organized as follows. In the next section we describe the baseline model, showing how networks, absorptive capacity and ambidexterity affect commercialization of innovations (CI). We began this section with defining the dependent variable of the study: CI. Then, we concentrate on describing each of the links that form the theoretical model. In the following section we further our discussion by extending and integrating previous literature to get a comprehensive view of how networks, absorptive capacity, and ambidexterity are related to each other. Our theoretical framework is comprised of (a) baseline model (Figure 1), which shows how all three constructs (networks, absorptive capacity and ambidexterity lead to CI and (b) an interplay model (Figure 2) that shows the relationships among the three constructs. We conclude with a discussion of the theoretical contributions and limitations of this work as well as our recommended directions for future research.

\section{Baseline Model: Factors Leading to Commercialization of Innovations}

\subsection{Dependent Variable: Commercialization of Innovations}

The innovation process is defined as the combined activities leading to new, marketable products and services and /or new product delivery systems (R.A. Burgelman, Christensen, \& Wheelright., 2006). Commercialization of Innovation (CI) has been defined as the act or activities required for introducing an innovation to market (Andrew \& Sirkin, 2003; Datta, 2011a; Kelm, Narayanan, \& Pinches, 1995; Kwak, 2002; Nambisan \& Sawhney, 2007; Narayanan, Pinches, Kelm, \& Lander, 2000; A. Nerkar \& Shane, 2007). Commercialization of innovation is often operationalized as the first sale of the target product or service (A. Nerkar \& Shane, 2007). However, when an innovation is introduced in the market, only technology enthusiasts procure, and such enthusiasts comprise less than three percent of the market (Moore, 1991). The larger mainstream market is comprised of pragmatists and conservatives, and so a successful commercialization is one that captures this mainstream market in which case the innovation is diffused across technology enthusiasts as well as pragmatists and conservatives (Moore, 1991, 2000). Reaching the mainstream market in this manner is difficult, and so we believe that the threshold for 'successful' commercialization of an innovation will 
likely lie somewhere between these two extremes - single sale on the one hand and saturating the mainstream of a market on the other. Converting technical innovations to products and services entails the development of manufacturing and marketing capabilities, and assets such as manufacturing facilities and service and distribution networks (Ahuja, 2000b; Mitchell, 1989; D.J. Teece, 1986; David J. Teece, et al., 1997).

We therefore define the CI as a firm's capacity to bring a product into a market and reach the mainstream of the market beyond the initial adopters. There are three aspects to our definition - (a) recognizes a market for an innovation (b) develops and manufacture it into a product and (c) sell/distribute the product through distribution channels. Of these, while the last two can be outsourced, the first one is of fundamental importance. Thus, commercialization of innovations primarily lies in an organization's ability to recognize current and emerging markets for current technological innovations and secondarily it depends on the firm's ability to manufacture and sell the product either buy itself or by subcontracting. In the following subsection-sections, we present a baseline model, in which we develop propositions that link networks, absorptive capacity and ambidexterity to CI. Figure 1 shows the base line model.

$<$ Figure 1 about here $>$

\subsection{Networks and Commercialization of Innovations}

Organizations enter alliances with each other to access critical resources, but they rely on information from the network of prior alliances to determine with whom to cooperate (Gulati \& Gargiulo, 1999). These new alliances modify the existing network, prompting an endogenous dynamic between organizational action and network structure that drives the emergence of external networks. While networks are formed to access and share resources (Dyer \& Singh, 1998; Gnyawali, He, \& Madhvan, 2006; Gulati, 1998; Gulati \& Kletter, 2005; Gulati, Nohria, \& Zaheer, 2000; R Klein, A Rai, \& D.W Straub, 2007; Pfeffer \& Salancik, 1978), these networks themselves become valuable resources (Barney, 1991; Mata, Fuerst, \& Barney, 1995; Melville, Kraemer, \& Gurbaxani, 2004; Porter, 1980; Ray, Muhanna, \& Barney, 2005).

Social, external and internal network are considered as three different types of networks, focusing on different levels of analysis, using different theoretical constructs, and explain different outcomes of networks (Van Wijk, 2003). Social networks consider organizations as social systems with a purpose, operating in a wider social structure. Organizations are differentiated by the network characteristics of the social relations they have with the society and other organizations (Nohria, 1992; Nohria \& Eccles, 1992). This perspective provides an analytical tool to investigate structural, relational and positional embeddedness, tie strengths and trust (Nahapiet \& Ghoshal, 1998). External network research focuses on networks as a governance mode intermediating markets and hierarchies - e.g., joint-ventures and strategic alliances. It highlights the competitive dimension of networks and therefore, focuses in particular on performance issues (Dyer $\&$ Singh, 1998). Internal network literature investigates intra-organizational structure and processes and management roles required for knowledge creation and sharing, maintaining flexibility, and enabling self-renewal (Henk W. Volberda, 1996; H.W Volberda \& Lewin, 2003).

While there is a clear distinction between internal and external networks, their outcomes can be overlapping. For instance, internal networks enable organizational self renewal (H.W Volberda \& Lewin, 2003), but it is not clear whether the influence of other networks were isolated while studying self-renewal. Similarly, the distinction between social and external networks is also not well defined. Social networks have often been included within the construct of interorganizational or external networks, like the inclusion of social interaction as an attribute of external networks (Provan, Fish, \& Sydow, 2007). The term interorganizational network is used interchangeably with strategic alliances, coalitions, and cooperative arrangements (Provan, et al., 2007), and has been tied to resource dependence theory (Pfeffer \& Salancik, 1978) transaction cost economics (Williamson, 1991), and interorganizational contracts (Ariño \& Reuer, 2006). Despite these differences argued that all definitions of external networks refer to common themes including social interaction, relationships, connectedness, collaboration, collective action, trust, and cooperation (Provan, et al., 2007). To reduce confusion, for the purpose of this paper we will only concentrate on external and internal networks, leaving out social networks.

The definition of networks could range from being very generic to extremely specific. From a generic standpoint a network as a set of nodes and the set of ties representing some relationship, or lack of relationship, between the nodes(Brass, Galaskiewicz, \& Greve, 2004), specifics included an overview of different types of external networks and then went into considerable detail in explaining how each is different within the rubric of networks as being constellations of organizations that come together through the establishment of social contracts or agreements (Barringer \& Harrison, 2000). 
Specifying the importance of networks in a multilevel approach, it has been argued that an organization's climate of innovation emerges from the shared perception of members of the organization on the degree to which organizational policies, resources, procedures and practices support and encourage innovation (Gupta, Tesluk, \& Taylor, 2007). The characteristics of an organization's network of social relations are relevant to a commercialization of innovations (Nohria, 1992; Nohria \& Eccles, 1992). Synthesizing the above, we therefore define networks as the collective of structures, and collaboration, within and between organizations. From an external network standpoint this includes networks between firms. From the standpoint of intraorganizational or internal networks, it includes organizational structure, top management teams, and behavioral context comprising performance management and social support. These networks themselves become a valuable resource, enabling organizational flexibility and leading to self-renewal.

\subsubsection{External Networks and Commercialization of Innovations}

Network linkages enable and constrain the flexibility, effectiveness, and innovativeness of organizational members (Burt, 1992). Being in a central position or having a direct link to the central node within an external network, firms are better able to access resources, such as finance, manufacturing facilities, distribution channels that help in commercialization of innovations (Gnyawali, et al., 2006; Richard Klein, Arun Rai, \& Detmar W. Straub, 2007). British hospitals were found to be less innovative than their U.S counterparts because they were less central in their interorganizational networks (Newell \& Clark, 1990). Hospitals that were centrally located in an interorganizational network were more likely to be early adopters of innovations than those outside the network (Burns \& Wholey, 1993) . Centrality determines the relative importance of an entity or a node in a network. While some organizations will struggle to get to the central position on any network to maintain competitive advantage, and control key resources, other organizations may try to link themselves to the central node (Dyer \& Singh, 1998; Gnyawali, et al., 2006; Gulati, 1995, 1998; Gulati \& Gargiulo, 1999; Gulati \& Kletter, 2005; Gulati, et al., 2000; Richard Klein, et al., 2007). Reasons for this difference in behavior could be many - it may be expensive for the entities to maintain and control such networks, or maybe the central node is a venture capitalist to which other nodes simply want to connect for financing, consulting, access to business incubators, or distribution channels. In this paper we restrict our dimensions of structure, norms or collaboration in external networks by the measured by centrality, and multiplexity of networks (Borgatti, 2005; Borgatti \& Everett, 2006; L. C. Freeman, 1977, 1979, 1980; Provan, et al., 2007; Wasserman \& Faust, 1994). Centrality is of three types: degree centrality, closeness centrality, betweenness centrality and eigenvector centrality.

Degree centrality is based on the number of direct links maintained by an organization with other organizations in the network (Borgatti, 2005; Borgatti \& Everett, 2006; C. Freeman, 1991; L. C. Freeman, 1977, 1979, 1980). The key question will be: does an organization occupy a central or a more peripheral position in the network based on the number of network ties it maintains with other organizations (Provan, et al., 2007).

Closeness centrality addresses the question of whether or not an organization is in a structural position to spread resources such as information or knowledge that might reside in any organization in the network, even through indirect ties (Provan, et al., 2007). Central organizations have short 'paths' (connections) to all other organizations in the network. Unlike degree centrality, indirect connections are viewed as valuable mechanisms for exchange of network-based resources in closeness centrality (Borgatti, 2005; Borgatti \& Everett, 2006; Datta \& Jessup, 2009; L. C. Freeman, 1977, 1979, 1980; Provan, et al., 2007; Wasserman \& Faust, 1994). Closeness can be regarded as a measure of how long it will take information to spread from a given vertex to other reachable vertices in the network. This is very important from the standpoint of entrepreneurship, where faster availability of information will result in competitive advantage.

Betweenness measures the influence a node has over the spread of information through the network (Newman, 2005). Vertices that occur on many shortest paths between other vertices have higher betweenness than those that do not (Datta \& Jessup, 2009; L. C. Freeman, 1977, 1979, 1980). If an organization serves as a gatekeeper within the network then, it must maintain intermediary links between organizations that are not directly connected with one another. Such organizations have benefits in accessing information about resources such as innovations and fundamental research with potential markets, funding opportunities, manufacturing facilities and distribution channels. Thus, these gatekeepers are potentially at a higher advantage in commercializing innovation.

Eigenvector centrality is a measure of the importance of a node in a network. It assigns relative scores to all nodes in the network based on the principle that connections to high-scoring nodes contribute more to the score of the node in question than equal connections to low-scoring nodes (Borgatti \& Everett, 2006; L. C. Freeman, 1977, 1979, 1980).

Multiplexity or diversity deals with the strength of the relationship an organization maintains with network partners, based on the number of types of links (e.g., research ties, joint programs, referrals, and shared personnel) connecting them (Provan, et al., 2007). Multiplexity also is referred to as heterogeneity of networks (Newman, 2001). Multiplex ties are thought to be an indicator of the strength and durability of an organization's links because they enable the connection 
between an organization and its linkage partner to be sustained even if one type of link dissolves (Provan, et al., 2007). Two entities that have collaborated in multiple arrangements are likely to know one another better on average than those who have few collaborations together. By multiple arrangements we mean either the entities are heterogeneous or the exchange of information is unique. Such uniqueness adds value to the network, necessary for commercialization of innovation to succeed. The strength of ties derived from each collaborative arrangement, in which a particular pair of entities participate, are added together.

Multiplexity or Diversity of external networks can also include ties with universities, national research laboratories and other research institutes that conduct basic research (Agarwal, 2006; Chataway \& Wield, 2000; Colyvas et al., 2002 ; R. Henderson \& Cockburn, 1996; R. Henderson, Jaffe, \& Trajtenberg, 1998; R. M. Henderson \& Clark, 1990; Jaffe, Trajtenberg, \& Henderson, 1993; Numprasertchai \& Igel, 2005). Firms communicate with institutes via formal and informal scientific meetings, licenses, joint ventures, research contracts, consulting, personal networks, research grants, recruitment of students, email, shared databases, workshops, communities of practice, and so on (L. Y. Cohen, Kamienski, \& Espino, 1998; W.M Cohen, Florida, Randazzes, \& Walsh, 1998; W. M. Cohen \& D. A. Levinthal, 1990; W. M. Cohen, Nelson, \& Walsh, 2002; Hoegl \& Schulze, 2005; Oliver, 2004; Walter.W Powell, 1998; Rothaermel \& Thursby, 2005; Salman \& Saives, 2005; Van den Bosch, Volberda, \& Boer, 1999). Through contracted, funded research, both the innovators and the commercializer benefit and the innovation/commercialization cycle appears to happen faster and more effectively (Birkinshaw \& Gibson, 2004). Such relationships help shorten the innovation cycle and promote faster commercialization.

Discovery of entrepreneurial opportunities is somewhat probabilistic in nature, as opposed to the result of a systematic search effort (Kirzner, 1997). Thus, diversity increases the probability of a successful search occurring (Kirzner, 1997). Also, because entrepreneurs seem best able to "discover" opportunities for commercialization that directly relate to their previous knowledge in the three dimensions of knowledge of markets, knowledge of how to serve those markets, and knowledge of specific customers' problems (Shane, 2000), a robust network is required to support information gathering, resource sharing, and idea generation. This knowledge is not equally distributed across all entrepreneurs and, therefore, is necessarily a function of their relationships with innovators, and funders (Anderson, 2008). Thus, recognition of an opportunity to commercialize an innovation is more likely to happen at the confluence of these entities, facilitated by the entrepreneurial entity and its corresponding network. Networks can help build entrepreneurial competency in all the entities in the network (Seppanen \& Skates, 2001) through knowledge sharing and transferring. Given that commercialization of innovation is key to creating entrepreneurial competency (Seppanen \& Skates, 2001), it follows that networks are critical to commercialization of innovation process. Synthesizing the above, we posit that networks and resources be they are within firm, among firms not only will help in opportunity recognition but also in manufacturing and distribution. Networks, thus help in moving innovations to markets, networks with financial agencies help raise funds for manufacturing, through networks firms can know if manufacturing can be outsourced to another entity or not and help in identifying the distribution channels for selling the products. This leads us to propose:

Proposition1a: Centrality, and multiplexity of external networks, positively affects commercialization of innovations. 2.2.2 Internal Networks and Commercialization of Innovations

In addition to external networks, past research also has contributed to our understanding of effects of internal networks on commercialization of innovations. The antecedents that have been studied have included a firm's behavioral context (Gibson \& Birkinshaw, 2004; A. A. Nerkar, et al., 1996; S. G. Scott \& Bruce, 1994) and the nature of top management teams within firms (Bantel \& Jackson, 1989; Ellis, 2003; Howell \& Higgins, 1990).

Organizational behavioral context comprises of performance management and social support (Gibson \& Birkinshaw, 2004). As such behavioral organizational context is important determinant of whether an organization can successfully recognize current and emerging market opportunities provided by centrality and multiplexity, which enhances commercialization of innovations. Highly innovative firms are expected to balance performance management and social support (Gibson \& Birkinshaw, 2004). Such a balance is reached through (a) leadership (leader member exchange, leader role expectation), (b) encouragement of individual problem solving style (intuition style and systematic style), and (c) work group relation influences the innovative climate of a firm comprising support for innovation (S. G. Scott \& Bruce, 1994) and subsequent commercialization. Thus, positive impacts of centrality and multiplexity on commercialization of innovation are enhanced further in presence of high performance behavioral context. This leads us to propose.

Proposition1b: Behavioral context within firms positively moderates the relationship between centrality and multiplexity of external networks on commercialization of innovations. 
In high-performance companies in commercializing innovations, top management maintain a visible presence to reinforce commercialization (Nevens, et al., 1990). Even in extremely decentralized and divisionlized firms like Hewlett Packard and 3M, top management feels free to go and meddle in issues crucial to commercialization process (Nevens, et al., 1990). Top management team in such firms do not distance themselves from the innovating and commercialization team (Nevens, et al., 1990). Further, top management teams act as tie breakers for dispute at project level, by giving precedence of commercialization related activities over others, by ensuring a deadline is met, clearing calendars of key employees off other work, speeding decision making, and making sure that the right people and the right people come together. Such behavioral integration of the top management with commercialization process, strengths the opportunity recognition and facilitation of emerging markets for innovations. Competitive organizations in response to technological innovation and extreme volatile environmental conditions are increasingly becoming horizontal in their reporting structure and reduced the levels of management between the CEO and the lowest levels by 25\% (Ellis, 2003). Such a reduction in the level of management between increases visibility and decreases the distance between top management and task forces of commercialization of innovations. Such a reduction in the levels of management decreases the time in which innovations from networks percolate within the organization.

Thus, we construe that behavioral integration of top management teams with innovation teams enhances the positive impact of centrality and multiplexity of external network has on commercialization of innovations. Thus, we posit:

Proposition 1c: Behavioral integration of Top Management positively moderates the relationship between external networks through centrality and multiplexity on commercialization of innovations.

\section{Absorptive Capacity and Commercialization of Innovations}

\subsection{Absorptive Capacity and Commercialization of Innovations}

Absorptive capacity is defined as the limit to the rate at which a firm can absorb scientific or technological information and/or a limit to the quantity of such information that can be absorbed (W. M. Cohen \& D. Levinthal, 1990; Jansen, 2005; Jansen, et al., 2005b). Conceptually, absorptive capacity is similar to information processing capacity but at the firm level rather than at the individual level. Absorptive capacity underlies a firm's knowledge capabilities by which the firm acquires, assimilates, transforms, and exploits knowledge resources to produce dynamic capabilities such as innovativeness (Zahra \& George, 2002) It is critical to developing competitive advantage and often leads to significant innovations (Walter. W Powell, Koput, \& Smith-Doerr, 1996). Todorova and Durisin (2007) conceptualized absorptive capacity as the capacity to recognize the value of knowledge, acquire, assimilate, transform, and exploit knowledge.

Zahra and George (2002) deconstructed absorptive capacity into potential and realized absorptive capacities. Potential absorptive capacity, which includes knowledge acquisition and assimilation, captures efforts expended in identifying and acquiring new external knowledge and in assimilating knowledge obtained from external sources (Zahra \& George, 2002). Realized absorptive capacity, which includes knowledge transformation and exploitation, encompasses deriving new insights and consequences from the combination of existing and newly acquired knowledge, and incorporating transformed knowledge into operations (Zahra \& George, 2002).

Absorption limits provide impetus for firms to develop internal R\&D capabilities. R\&D departments then not only perform their work along with lines with which they are already familiar, but also they can extend their work to include new ideas and, in particular, incorporate new knowledge that is external to the firm. Absorptive capacity enables firms to predict more accurately the mature and commercial potential of technological advances (W. M. Cohen \& D. A. Levinthal, 1990) In other words, a higher absorptive capacity and/or efforts to increase absorptive capacity can both promote innovation within a firm as well as a firm's ability to manage innovation effectively. In fact, realized absorptive capacity converts knowledge into products, services, and technologies. By the combination of potential and realized absorptive capacity firms increase the distinctiveness of their innovations (Yli-Renko, Autio, \& Sapienza, 2001) and are able to develop new innovations that differ substantially from existing products, services, and processes, without hampering existing lines.

Realized absorptive capacity converts knowledge into products, services, and technologies (Jansen, et al., 2005b). By the combination of potential and realized absorptive capacity firms increase the distinctiveness of their innovations (Yli-Renko, et al., 2001) and are able to develop new innovations that differ substantially from existing products, services, and processes.

In our definition of commercialization of innovations, we included organization's ability to recognize current and emerging markets as a fundamental component. Absorptive capacity is the limit to the rate at which a firm can absorb scientific or technological information. Without being cognizant on absorbing scientific of technological innovations, it 
is impossible to visualize a market for such innovations. Thus, without absorptive capacity the fundamental requirement to commercialize innovation will not be reached. This leads us to propose:

\section{Proposition 2: Higher absorptive capacity increases commercialization of innovations.}

\subsection{Ambidexterity and Commercialization of Innovations}

The key to firm longevity is in being innovative (O'Reilly \& Tushman, 2004; Tushman \& O'Reilly, 1996b, 2002). From the discussion of types of balance it can be concluded that ambidextrous organizations are naturally innovative and have the ability to renew themselves by creating breakthrough products for existing markets and capitalizing on emerging markets (Brikinshaw \& Gibson, 2004; Gibson \& Birkinshaw, 2004; O’Reilly \& Tushman, 2004; Raisch \& Birkinshaw, 2008; Tushman \& O'Reilly, 1996b, 2002; H.W Volberda \& Lewin, 2003). Specifically, such organizations have been able to compete in mature market segments through incremental innovations (Abernathy \& Utterback, 1978; C.M. Christensen, 1992a; C.M. Christensen, 1992b) and in emerging market segments through radical innovations (Abernathy \& Utterback, 1978; Robert A. Burgelman, 2002; R.A. Burgelman, et al., 2006; R A Burgelman \& Grove, 1996; C.M. Christensen, 1992a; Galunic \& Eisenhardt, 1996; R. M. Henderson \& Clark, 1990). Being ambidextrous enables a firm to diversify its skills to combine current opportunities with future vision. For instance, the ability of Hewlett Packard to balance its mainstream computing and printing market with emerging IT service markets led to leading products in computers, printers and IT services like HP Open View.

Ambidextrous firms reconcile conflicting demands from their task environment and synchronize and balance concurrent exploration of new opportunities and exploitation of existing ones (Brikinshaw \& Gibson, 2004; Duncan, 1976; Gibson \& Birkinshaw, 2004; O’Reilly \& Tushman, 2004; Tushman \& O’Reilly, 1996b). In this way, ambidextrous organizations can renew themselves through the creation of breakthrough products, services and processes without destroying or hampering their traditional businesses (Gibson \& Birkinshaw, 2004; Tushman \& O'Reilly, 1996b; H.W Volberda \& Lewin, 2003).

Ambidexterity is frequently depicted using a variety of oppositional concepts. The most accepted definition of ambidexterity in the current literature is a balance between explorations and exploitation. These organizations are capable of exploiting their existing competencies while exploring new opportunities at the same time (Bodwell \& Chermack, 2009; Lubatkin, et al., 2006; March, 1991; O'Reilly \& Tushman, 2007). March (1991) referred to this as the exploration of new possibilities and the exploitation of old certainties. Exploitation includes such things as refinement, choice, production, efficiency, selection, implementation, execution (March, 1991). Adaptive systems that engage in exploration to the exclusion of exploitation are likely to find that they suffer the costs of experimentation without gaining many of its benefits (March, 1991). They exhibit too many undeveloped new ideas and too little distinctive competence. Conversely, systems that engage in exploitation to the exclusion of exploration are likely to find themselves trapped in suboptimal stable equilibrium. As a result, maintaining an appropriate balance between exploration and exploitation is a primary factor in system survival and prosperity. (March, 1991).

Similar to March's (1991) assertion is the balance between adaptability and agility as depicted by Birkinshaw and Gibson (2004). They defined the trade-offs between alignment and adaptability as foundational to organizations and describe organization ambidexterity as the capacity to simultaneously achieve alignment (excellence in daily operations) and adaptability (referring to the organization's ability to innovate and change in response to changing demands in the environment). To ensure long-term success, an organization needs to master both adaptability and alignment - a dual mode, known as ambidexterity (Birkinshaw \& Gibson, 2004; Gibson \& Birkinshaw, 2004; Hansen \& Birkinshaw, 2007; Hill \& Birkinshaw, 2006; Raisch \& Birkinshaw, 2008).

For example, while Nokia launched a vast array of new mobile technology product offerings, it also continued to make pricing and other product-product decisions in order to sustain its position as one of the leading handset providers (Birkinshaw \& Gibson, 2004). Focusing too much on alignment makes an organization lose long-term vision, while emphasizing adaptability over alignment means building tomorrow's business at the cost of today's (Birkinshaw \& Gibson, 2004; Gibson \& Birkinshaw, 2004). Similarly, in order to innovate successfully, organizations must balance two stages of innovation, namely: initiation and implementation - again termed as ambidexterity (Duncan, 1976). Specifically, during the initiation phase, an organization needs low formalization and low centralization, whereas during implementation phase it tends to follow high formalization with low complexity and high centralization.

Seen from Birkinshaw and Gibson's (2004) perspective, March's exploration would be substantiated by Nokia's experiment with newer technology and exploitation would be their continuing investment and commitment in their existing product lines. Exploration encompasses knowledge creation and analysis of emerging and future opportunities, while exploitation is defined as making use of existing knowledge to leverage current opportunities (March, 1991; Sidhu, 
Commandeur, \& Volberda, 2007; Sidhu, Volberda, \& Commandeur, 2004; Wielemaker, 2003; Zack, 1999, 2003). Other scholars have used different words to attribute similar oppositional meanings of the concepts relevant to the notion of organizational ambidexterity. For example:

1. The paradox of administration involves the dual searches for certainty and flexibility (Thompson, 1967).

2. Ambidexterity is an acceptable solution to the battle between efficiency (exploitation activities) and flexibility (exploration activities) (Adler, Goldoftas, \& Levine, 1999).

3. Ambidextrous organizations as those able to reconcile agility and stability (Vinekar, Slinkman, \& Nerur, 2006). In their view, an agility approach is suitable for projects with high levels of uncertainty and risk and frequently changing environments. A stability approach is appropriate for projects in which the requirements are stable and predictable, and when the project is large, critical, and complex. But firms that pursue both anticipatory and hindsight actions at the same time enable managers to exercise better strategic control and optimize the firm's short-run performance as well as long-term prospects.

4. Strategic planning activities can be anticipatory or hindsight in orientation. Anticipatory activities seek to proactively take advantage of the future in order to reduce the organization's environmental uncertainty (Veliyath, 1992). Hindsight activities rely on ex-post analysis of events and information to prepare for the future (Veliyath, 1992).

5. Ambidexterity as a balance between incremental and innovation and change (Tushman \& O'Reilly, 1996a).

A common thread that runs through all the seemingly varied views on ambidexterity is that instead of choosing between the two extreme ends of a spectrum, ambidexterity is about striking a 'balance' (Bodwell \& Chermack, 2009; Collin \& Porras, 1997; Eisenhardt, 2000; Lewis, 2000). In other words, it is about balancing seemingly contradictory tensions be it exploration \& exploitation, adaptability \& agility, initiation \& implementation, emergent \& deliberate, radical \& incremental innovations and so forth. While exploration, adaptability, initiation, radical and emergent are explorative ends of the spectrum; exploitation, agility, implementation, incremental and deliberate are exploitative ends of the spectrum. Concentrating only on one aspect would help us address the core of ambidexterity: balance between opposing forces. For the purpose of this paper we chose exploration and exploitation. We thus define and restrict our definition of ambidexterity as the property of an organization to balance the two activities of exploration and exploitation. Exploration requires significant investments with uncertain payoffs (Bodwell \& Chermack, 2009; Siggelkow \& Levinthal, 2003). Exploitation focuses on incremental change to create value through existing competencies, and thus poses less risk to the organization. Exploitation is an orientation to the short-term whereas exploration has a more future-based, or long-term focus (Bodwell \& Chermack, 2009; He \& Wong, 2004). Exploitation activities may be directed toward gaining efficiency while exploration activities promote flexibility in the organization. The exploration versus exploitation construct has been used in a "wide range of management research areas, including strategic management, organization theory, and managerial economics (Bodwell \& Chermack, 2009; He \& Wong, 2004).

A point of distinction between ambidexterity and absorptive capacity is warranted before taking the discussion forward. Potential absorptive capacity contains exploration and realized absorptive capacity contains exploitation in its construct definition (Zahra \& George, 2002). These are the capabilities associated with increasing the information processing capacity at firm level. Ambidexterity on the other hand, despite having two core concepts of exploitation and exploration is about making a strategic choice of selecting both dimensions rather than choosing one over the other. Thus, while potential absorptive capacity is increased when firms explore, its exploitation increases the realized absorptive capacity, ambidexterity is enhanced when firms simultaneously pursue both. And, the definition of exploration and exploitation in context of ambidexterity ranges from very generic to extremely specific (emergent versus deliberate strategies, radical versus incremental innovations, adaptability versus agility ), while with absorptive capacity it is specifically concerned with expanding a firm's information processing capacity.

The ability of ambidextrous firms to come up with radical new products without hampering the existing markets, make them long-lived (O'Reilly \& Tushman, 2004; Tushman \& O'Reilly, 1996b, 2002). Long lived-firms have several structural and cultural similarities (Collin \& Porras, 1999; Huygens, Van Den Bosh, Volberda, \& Baden-Fuller, 2001; Porter, 1998; Van Wijk, 2003). Factors within firms that affect ambidexterity include decentralization, a tolerant management style, and sensitivity towards the emerging trends in the environment. Combining work on corporate longevity and co-evolutionary theory, Volberda and Lewin (2003) proposed three key principles of self renewal within organizations: (a) self-renewing organizations focus on managing requisite variety by regulating internal rates of change equal to or exceed external rate of environmental change triggered by customer orientation, technology innovation, industry competition, and product obsolescence; (b) self-renewing organizations optimize self-reorganization; and (c) 
self-renewing organizations synchronize concurrent exploitation and exploration (Levinthal, 1997; Levinthal \& March, 1993; Lewin \& Volberda, 1999; March, 1991).

Thus, the balance between exploration and exploitation arises from sensitivity to the environment and maintaining a compatible organizational structure, which in turn produces organizational longevity. Organizations that are capable of simultaneously building new capabilities and using existing capabilities, (i.e., harmonic ambidexterity) enjoyed higher levels of venture strategic performance through the creation of breakthrough innovations by investing in disruptive technologies (Hill \& Birkinshaw, 2006). Technologically oriented organizations that engage in successive or cyclic rounds of exploitation and exploration are best equipped to pursue product innovations (Simsek, 2009; Simsek, et al., 2009; Tushman \& O'Reilly, 1996a). By engaging in intensive periods of exploration, business units discover new technologies that not only spur the proliferation of new products, but that may even become established as the dominant design in the industry (R. M. Henderson \& Clark, 1990). Then, by subsequently shifting to exploitation, business units improve the performance of product innovations through process innovation (Simsek, et al., 2009). Large corporations, such as Johnson \& Johnson, and Asea Brown Boveri (ABB), have been able to compete in mature market segments through incremental innovation, and in emerging market segments through discontinuous innovation (Tushman \& O'Reilly, 1996a, 2002). They reconcile conflicting demands from their task environment and synchronize and balance concurrent exploration of new opportunities and exploitation of existing ones (Birkinshaw \& Gibson, 2004; Duncan, 1976; Gibson \& Birkinshaw, 2004; Raisch \& Birkinshaw, 2008; Tushman \& O'Reilly, 1996a). In this way, ambidextrous organizations can renew themselves through the creation of breakthrough products, services and processes without destroying or hampering traditional businesses (Birkinshaw \& Gibson, 2004; Gibson \& Birkinshaw, 2004; Raisch \& Birkinshaw, 2008; Tushman \& O’Reilly, 1996a; H.W Volberda \& Lewin, 2003).

We already have mentioned that ambidextrous firms are better able to attain organizational longevity, and that such long-lived organizations compete in mature market segments through incremental innovations (Abernathy \& Utterback, 1978; C.M. Christensen, 1992a; C.M. Christensen, 1992b) and in emerging market segments through radical innovations (Abernathy \& Utterback, 1978; Robert A. Burgelman, 2002; R.A. Burgelman, et al., 2006; R A Burgelman \& Grove, 1996; C.M. Christensen, 1992a; C.M. Christensen, 1992b; Galunic \& Eisenhardt, 1996; R. M. Henderson \& Clark, 1990). For instance, the ability of Hewlett Packard to balance its mainstream computing and printing market with emerging IT service markets led to leading products in computers, printers and IT services, like HP open view. Thus, being ambidextrous leads a firm to combine current opportunities with future vision, which, per our definition of commercialization of innovation, includes being able to recognize current and emerging markets. Further, we have argued that the ability to balance exploration and exploitation leads to an organization's being cognizant of existing and emerging markets, and capitalize on both types of market opportunities. Thus we propose:

Proposition 3. Better the balance between exploitation and exploration higher probability of commercialization of innovations.

\section{Interplay Model: Relationships among Networks, Absorptive Capacity and Ambidexterity}

In this section we describe how the antecedents to commercialization of innovations: Networks, Absorptive Capacity and Ambidexterity relate to each other. Figure 2 depicts the relationship. The base line mode in figure 2 is shown in dotted lines.

$<$ Figure 2 about here $>$

\subsection{Internal \& External Networks and Absorptive Capacity}

Networks are salient to absorptive capacity and important for increasing a firm's knowledge base in conjunction with its business partners and for creating new knowledge, which can be observed in the form of new patents (which are embodiments of knowledge), new categories of products and services (which come from understanding the competition and market needs), and in extreme cases, creation of new industries (Jansen, et al., 2005b). Networks also play an important role in building a firm's absorptive capacity by providing skills and processing abilities that can support acquisition, assimilation, transformation, and exploitation of knowledge to create innovation (Alavi \& Leidner, 2001; Jansen, et al., 2005b; Lane, et al., 2006; Lane \& Lubatkin, 1998; Lane, et al., 2001; Todorova \& Durisin, 2007).

The primary antecedents to absorptive capacity lies in the structure of communication between organizations: outward absorptive capacity; the structure of communication between subunits in the organization: Cross-functional absorptive capacity, and the structure of communication within subunits in the organization: inward absorptive capacity (Cohen \& Levinthal, 1990). The latter is self evident insofar as good communication within units will permit more and quicker absorption of knowledge than will poor communication, but outward and functional absorptive capacity need some illustration and explanation. 
Outward absorptive capacity results in the experiences or knowledge of one firm or entity increases the limit of absorption of the other entity over the network. For example the strategic partnership between Intel and Microsoft (Grove, 1996) leads to collaborative learning for new products introductions. An example of cross functional absorptive capacity is the tight linkage between design and manufacturing sub-units that has enabled Japanese manufacturing firms to move products rapidly from design through production, marketing, sales, and into the market (Clark \& Fujimoto, 1987; W. M. Cohen \& D. Levinthal, 1990). Overlapping product development cycles facilitated collaboration and coordination across subunits within a firm (Clark \& Fujimoto, 1987).

In studying the organizational antecedents to absorptive capacity (Jansen, et al., 2005b), distinguished between potential and realized absorptive capacity using work of (Zahra \& George, 2002). Potential absorptive capacity, which includes knowledge acquisition and assimilation, captures efforts expended in identifying and acquiring new external knowledge and in assimilating knowledge obtained from external sources (Zahra \& George, 2002). Realized absorptive capacity, which includes knowledge transformation and exploitation, encompasses deriving new insights and consequences from the combination of existing and newly acquired knowledge, and incorporating transformed knowledge into operations (Zahra \& George, 2002).

An organic structure that better enables people to solve unstructured problems quickly and well is desirable in promoting absorptive capacity (Chen, 2004; W. M. Cohen \& D. A. Levinthal, 1990; Jansen, et al., 2005b). Since structure and collaboration are essential elements of intraorganizational network, we can conclude that networks within an organization can affect its absorptive capacity. The effect of cross-functional interfaces, organizational networks, and socialization on absorptive capacity (Jansen, et al., 2005b) Past research has shown the effect of combinative capabilities on absorptive capacity (Kogut \& Zander, 1992; David J. Teece, et al., 1997; Van den Bosch, et al., 1999).

Three attributes of internal networks within firms are essential in explaining absorptive capacity would be: behavioral context, top management team and structure. Cross-functional interfaces, job rotation, participation in decision have a positive relationship, while, formalization, routinization, connectedness and socialization has a negative relationship with potential absorptive capacity (Jansen, et al., 2005b). Similarly, cross-functional interfaces, job rotation, formalization, routinization, connectedness and socialization tactics have a positive relationship, while participation in decision making has a negative relationship with realized absorptive capacity (Jansen, et al., 2005b). Essentially, formalization and routinization is a part of organizational structure. Density of linkages or connectedness and socialization tactics serves as the dual purpose of performance and socialization of behavioral contact (Gibson \& Birkinshaw, 2004). Participation of subordinates in decision making touches both organization structure, and top management team through behavioral integration. Job-rotation allows enhancing redundancy as well as diversity of backgrounds, to increase problem-solving skills, and to develop organizational contacts (W. M. Cohen \& D. A. Levinthal, 1990; Jansen, et al., 2005b). This is again, not possible without encouragement from top management. Cross functional interface between units, increases cross-functional absorptive capacity (Clark \& Fujimoto, 1987; W. M. Cohen \& D. A. Levinthal, 1990). Cross functional interface cannot exist without behavioral integration from top management. Thus, top management teams (cross-functional interfaces, job rotation: positive; participation in decision making: negative) and organizational structure (formalization, routinization: positive) has a mixed impact, while behavioral context (connectedness and socialization: positive) has a positive impact on realized absorptive capacity.

\section{Proposition 4a: Top management teams, has a positive relation, while organizational structure and behavioral context has a negative relationship with potential absorptive capacity. \\ Proposition 4b: Top management teams and organizational structure has a mixed while behavioral context has a positive impact on realized absorptive capacity.}

Antecedents to absorptive capacity in addition to the internal networks are networks between organizations and research laboratories (W. M. Cohen \& D. A. Levinthal, 1990). To expand on the knowledge that is absorptive capacity, some previous fundamental knowledge is necessary, and so the significance of fundamental research and tie ups with professional research institute were emphasized. Thus, relationships between firms and firms with research laboratories and academia affect a firm's absorptive capacity (W. M. Cohen, et al., 1998; W.M. Cohen, Goto, Nagata, Nelson, \& Walsh, 2002; W. M. Cohen \& D. A. Levinthal, 1990). In fact taken from structural standpoint of external networks in terms of centrality and multiplexity both affects absorptive capacity.

Publications, public meetings and conferences, informal and personal exchanges of information, and consulting contracts are the four primary channels for knowledge exchange between firms and research laboratories and academia (W. M. Cohen, et al., 1998; W.M. Cohen, et al., 2002). Networks between academia and industry can benefit participating firms in that there is a useful flow of knowledge and, in some contractual cases, intellectual property itself from the laboratories and academia to the business partner either in the sharing of research findings and/or through the guidance of the scientist 
(e.g., if the scientist were to serve as an advisor or board member for the participating firm. These types of networks between firms and research laboratories/ academia expand an organization's absorptive capacity (W. M. Cohen \& D. A. Levinthal, 1990). Taking these arguments from the standpoint of multiplexity of networks, we argue that diverse networks can increase a firm's potential absorptive capacity. With a diverse network a firms is able to able to acquire and assimilate knowledge from an assortment of sources which enhances its ability to process external knowledge. In fact acquisition of external knowledge from external sources is part of the definition of potential absorptive capacity (Zahra \& George, 2002). A firm that resides within a homogenous network is crippled in terms of absorbing multiple perspectives of a problem or a solution domain. Diverse or multiplex of ties enable a firm to gather information from multiple sources and therefore increases the probability of acquisition and assimilation diverse external knowledge. Diverse ties also help firms amplify its potential to gain information about technological innovations, business opportunities, sources of capital and so forth (Ahuja \& Lampert, 2001; Lane \& Lubatkin, 1998). Thus multiplexity of ties leads firms to access complimentary resources (Burt, 1992). Hence, diverse ties help on augment potential absorptive capacity. Centrality too plays a positive role on the other hand plays a dual role in affecting potential absorptive capacity.

Centrally located organizations are well positioned in terms of reaping benefits of knowledge spillovers, information flows and innovations by peripheral actors (Bell, 2005; Walter. W Powell, et al., 1996; Soh, 2003). In fact the positive impact of spillovers and information flow on absorptive capacity (W. M. Cohen \& D. A. Levinthal, 1990). But for very large or small networks, centrality leads to zero or diminishing returns on potential absorptive capacity. When the size of a network gets bigger, centrality imposes information overload, thereby reducing the information processing capacity of the organization. As already stated (W. M. Cohen \& D. A. Levinthal, 1990), that absorptive capacity is information processing capacity at the organizational level, we pose that for larger networks centrality is counterproductive to potential absorptive capacity. In similar when the network is sparse, then the influx of information may be comprehensive enough to increase an organizations absorptive capacity. Thus, there is an optimal size of a network under which the positive effects of multiplexity does not outweigh the positive effects of centrality on potential absorptive capacity. This leads is to propose.

Proposition 4c: External networks through multiplexity and centrality affects a firm's potential absorptive capacity. Such that multiplexity positively affects and centrality has an inverted u-shaped relationship with potential absorptive capacity. While diverse ties have a positive relationship with potential absorptive capacity, the relationship with realized absorptive capacity is quite different. While informal mechanism helps in exchanging ideas, formal systematic mechanisms are systematic for exploitation of transformation of knowledge into operations (Zahra \& George, 2002). Diverse ties bring new insights and consequences to acquired knowledge, but to boost the realized absorptive capacity, one needs the diversity in the light of systematic and formal approach. This is similar to Duncan's (1976) argument that organizations need to work on a dual mode to be innovative. During initiation, it should have low formalization, low central control, and highly complex organization of entities (Note 1). During implementation, however, the organization must work under high formalization, high central control, and low complexity of organization of entities. Thus, multiplexity or diversity of ties can have a positive effect of realized absorptive capacity only if pursued under the lens of formal, mechanistic mechanisms.

Centrality has a more positive impact on realized absorptive capacity than it has on potential absorptive capacity. It can be the means to keep the formal mechanism in place necessary to achieve realized absorptive capacity. For instance, in a dense network, when it is necessary to exploit and transform knowledge, centrality helps in filtration required to check in multiple influx that might lead to digression. While the influx of ideas is necessary for potential absorptive capacity, where multidimensional external view adds organizational knowledge, during exploitation or transformational phase such influx will cause result foray, compromising on the realized absorptive capacity.

Proposition 4d: External networks through multiplexity and centrality affects a firm's realized absorptive capacity. Such that, multiplexity positively affects realized absorptive capacity only under the lens of formal mechanisms, and centrality a positive effect of realized absorptive capacity.

\subsection{Networks and Ambidexterity}

There are four ways to strike a balance between exploration and exploitation: harmonic, cyclical, partitional and reciprocal (Simsek, 2009; Simsek, et al., 2009). Harmonic balance is achieved through concurrently pursuing exploitation and exploration harmoniously within a single organizational unit (Simsek, et al., 2009). Such a balance competes for scarce resources, leading to conflicts, contradictions, and inconsistencies. Organizational practice and routines are viable antecedents of harmonic balance.

Cyclical ambidexterity is a type of balance in which organizations engage in long periods of exploitation (or relative stability), interspersed by sporadic episodes of exploration (or change). Simsek, et al. (2009), related it to punctuated 
equilibrium (Gersick, 1991). Antecedents to cyclical ambidexterity are found in human resource practices that emphasize innovation, teamwork, and flexibility (Simsek, et al., 2009).

Simsek, et al. (2009) traced back partitional ambidexterity to Duncan's (1976) work, on the role of dual structure of initiation and implementation. Organizational theorist (O'Reilly \& Tushman, 2004; Tushman \& O'Reilly, 1996b) envision partitional ambidexterity as an interdependent, simultaneous phenomenon, involving the compartmentalizing and synchronizing of exploitation and exploration within different structural units an organization. From a structural perspective, partitional ambidexterity is achieved by creating separate units or divisions for exploitation and exploration (Duncan, 1976; O'Reilly \& Tushman, 2004; Tushman \& O’Reilly, 1996b), with each unit embodying distinct strategic and operating logics, cultures, and incentive systems. The ability to simultaneously pursue both exploitation and exploration results from "hosting multiple contradictory structures, processes, and cultures within the same firm" (O'Reilly \& Tushman, 2004). While tightly integrated at the business unit level, these logics must remain loosely coupled across business units (Benner \& Tushman, 2003). In addition, Simsek, et al. (2009) suggested antecedents to partitional ambidexterity that extend across organizations by using external networks. In a study of almost 20,000 alliances over a period of ten years, it observed that exploitation and exploration can be pursued both within and across three domains of strategic alliances including the value chain function of alliances, the attributes of alliance partners, and the network position of alliance partners (Lavie \& Rosenkopf, 2006).

Reciprocal interdependence occurs when the outputs of exploitation from a business unit become the inputs for exploration by a second business unit and the outputs of second business unit cycle back to become the inputs of the first business unit (Simsek, et al., 2009). Ongoing information exchange between organizational units or between organizations enables this. Firms appear to balance their tendencies to explore and exploit with respect to the nature of their alliances or choice of partners over time and across domains (Lavie \& Rosenkopf, 2006). Their findings highlight the significance of alliances and external networks as mechanisms for combining exploitation and exploration across time and units. In this vein, knowledge integration among alliance partners may be especially relevant to the pursuit of this form of ambidexterity (Simsek, et al., 2009).

\subsubsection{External Networks and Ambidexterity}

In our discussion of the types of balance (harmonic, cyclical, partitional, and reciprocal), we found that ambidexterity is enabled by the networks (Birkinshaw \& Gibson, 2004; Gibson \& Birkinshaw, 2004; Raisch \& Birkinshaw, 2008). Collaboration within and among organizations and between organizations and research laboratories/academia affects an organization's ability to strike a balance between exploration and exploitation.

From a very specific standpoint, multiplexity and centrality (or diversity) of networks affect ambidexterity (Simsek, 2009; Simsek, et al., 2009). Network diversity affords the organization multiple benefits from the perspectives of attaining ambidexterity. First, it affords the organization with the benefit of heterogeneity in its problem-solving machinery (Simsek, 2009). An organization that has a homogenous network has little opportunity to consider multiple perspectives because most network members see the world similarly. In contrast, diverse ties imply organizations that may differ in their modes of reasoning, problem formulation and solution. Exposure to these different approaches adds to the repertoire that the organization can bring to bear on exploitation and exploration. For example, it may lead to constructive conflict, yielding deeper and more comprehensive analysis of design problems, and novel framing of opportunities (Baum, Calabrese, \& Silverman, 2000; Beckman \& Haunschild, 2002; Simsek, 2009). Second, diverse network ties are valuable to ambidexterity because they can help the organization overcome the familiarity trap, that is, a tendency to favor the familiar over the unfamiliar (Ahuja \& Lampert, 2001; Simsek, 2009). Third, diverse ties can also promote ambidexterity by enabling organizations overcome the convenience trap, a tendency to search for solutions that are in the neighborhood of existing solutions rather than search for completely new solutions (Ahuja \& Lampert, 2001; Simsek, 2009). Diverse ties enable the organization to access a wider circle of information about potential markets, new business opportunities, innovations, and sources of capital, and potential customers.

Thus, an organization with heterogeneous partners is likely to not only have access to more complementary resources but also to know more about how to productively put these resources into use (Burt, 1992; Simsek, 2009). For example, through its strong relation with universities in Finland, Nokia is able to experiment with a vast array of new mobile technology inventions (such as the Nokia Symbian operating system) relatively inexpensively, while continuing to invest in being the dominant handset franchise, thereby enabling its ambidexterity (Birkinshaw \& Gibson, 2004). The above discussion leads us to propose:

\section{Proposition 5a: Diversity of ties among organizations and with academia/ research laboratories positively affects} ambidexterity.

Central organizations, because of their more numerous direct and indirect connections to others, have more relationships to draw upon in obtaining resources and so are less dependent on any single organization to explore (J. Scott, 1991). In 
addition, the access facilitated by centrality means a higher likelihood of exposure to the various disparate social circles within the network and to more clusters, or pockets, of highly connected organizations (Walter. W Powell, et al., 1996; Simsek, 2009). As a consequence, exploitation is also enabled because central organizations become better informed about what is going on in the network. Centrality is likely to present information and resource advantages that are beneficial to the attainment of ambidexterity (Simsek, 2009). An organization that is centrally located in a network with respect to others is likely to expect greater benefits in terms of knowledge spillovers, information flows and innovations by peripheral actors (Bell, 2005; Walter. W Powell, et al., 1996; Soh, 2003). Since central organizations have direct or indirect relationships, they can explore and access resources through multiple relationships and thus are less dependent on any single entity (J. Scott, 1991; Simsek, 2009). Further, exploitation is also enhanced because central organizations are well informed about what is going on in the networks (Simsek, 2009), for instance which are the key resources for manufacturing, distribution channels and so forth. Organizations become well informed by centrality through higher likelihood of exposure to contrasting social circles (Simsek, 2009).

On the negative side, there may be a diminishing point of returns to centrality (Ahuja \& Katila, 2001; Ahuja \& Lampert, 2001; Katila \& Ahuja, 2002; Ocasio, 1997; Simsek, 2009). The existence of an inflection point in the relationship between centrality and ambidexterity is related to allocation of attention and information overload (Ocasio, 1997; Simsek, 2009). This is particularly true when the size of the network is very high or when the network is very dense, or when there are many entities in a network. From the standpoint of allocation of attention, it can be argued that, centrality might pull organizations into several directions (J. Scott, 1991; Simsek, 2009) because central organizations over a large network can spend limited amount of time to each contacts. Thus, intensity of contacts diminishes and useful resources and information are less likely to surface (Ahuja \& Lampert, 2001; Simsek, 2009). Large quantities of information originating from diverse sources, can overload an organizations information processing capacity. Owing to organization's the limited information processing capacity, information overload arising from networks may be counter-productive. To counteract this, organizations would develop and routinize information filters and focus on certain type of information, while disregarding others (Simsek, 2009). Thus, organizations when information munificence is low, organizations process less information; when moderate, highest amount of information is processed; and when, cognitive strain leads to reversing to less amount of information processing (Koka \& Prescott, 2002; Simsek, 2009). Thus, centrality has an inverse U shaped relationship with respect to ambidexterity. When the network size is small or too large, there will no or diminishing returns, while at a moderate size of network, centrality can positively affect ambidexterity. This leads us to propose:

Proposition 5b: Centrality has an inverted u-shaped relationship with ambidexterity. Such that at moderate levels of network population, ambidexterity is maximized.

\subsubsection{Internal Networks and Ambidexterity}

From the standpoint of internal networks, decentralized structure, a common culture and vision, and supportive leaders and flexible managers are key sources of ambidexterity (Tushman \& O'Reilly, 1996a). Other aspects of intraorganizational networks considered were roles of dual structures, behavioral context and top management teams (Simsek, 2009).

Attributes of organizational structural architecture affects its ability to attain ambidexterity (Simsek, 2009). Specific to this was the concept of duality, where some business units focus entirely on exploration and some on exploitation. Such a structure leads to parallel attainment of exploration and exploitation, without conflict for resources. From an interorganizational standpoint networks with academia/ research laboratories too gives a temporal separation of exploration and exploitation, where the innovations explored by academia/ research laboratories are exploited by the organization. In presence of a dual structure, organizations are more likely to extract from its network and ties information and knowledge pertinent to ambidexterity (Simsek, 2009). From a specific standpoint, dual structure minimizes the negative impact of information overloading on ambidexterity those central organizations from a large network experiences (Katila \& Ahuja, 2002; Ocasio, 1997; J. Scott, 1991; Simsek, 2009). The reason is small and decentralized exploratory units will more effectively extract exploratory information while more centralized tight cultures and processes of exploitation units will extract exploitative information. Thus, while moderate levels of centrality are most conducive to ambidexterity, this relationship is strengthened in presence of dual structure. In the same vein, dual structural architectures provide organizations with enhanced capabilities to handle information influx from diverse or multiplex or diverse networks. In presence of the dual structure, the cost and effort to handle information flood from diverse networks is controlled (Ocasio, 1997; Simsek, 2009). With diversity of ties, the cost of technological and organizational challenges to integration increases. In fact, more diverse the knowledge the more complex is the problem of creating and managing integration. With dual structures, an organization can boost its ability to identify valuable knowledge, develop connections and combine information that promotes ambidexterity (Simsek, 2009). Combining the arguments relating to the roles of dual structure on centrality and multiplexity of networks, we propose: 
Proposition 5c: The dual structure architecture within firms positively moderates the relationship that interorganizational network through centrality and multiplexity has on ambidexterity.

An organizational behavioral context comprising performance management and social support enhances its ability to enhance ambidexterity (Gibson \& Birkinshaw, 2004). High performance organizational context is expected to balance performance management and social support (Birkinshaw \& Gibson, 2004). Organizational context as an important determinant of whether an organization can leverage opportunities of ambidexterity provided by centrality and multiplexity (Simsek, 2009). In a high performance context, an organization is dynamic and flexible enough to allow its members to pursue exploration and exploitation, both and which are scrutinized and rewarded (Simsek, 2009). Inductively speaking, therefore, positive impacts of centrality and multiplexity on ambidexterity are enhanced further in presence of high performance organizational context. Specifically, high performance context can dampen and strengthen the negative effects of high centrality and moderate centrality, and also amplify the positive effect of multiplexity on ambidexterity (Simsek, 2009). In other words, high performance organizational context plays a moderating role on the effect centrality and multiplexity has on ambidexterity. This leads us to propose:

Proposition 5d: Behavioral Context within firms positively moderates the relationship between external networks through centrality and multiplexity on ambidexterity.

Top management teams makes decisions regarding organizational forms, cultures and resource allocation processes to enable a balance between exploration and exploitation (Smith \& Tushman, 2005). Ambidexterity is facilitated by top management's internal processes which enable them to handle large amount of information ad decision alternatives and deal with conflict and ambiguity (Tushman \& O'Reilly, 1996a). Top management's behavioral integration is a key contributor to ambidexterity (Lubatkin, et al., 2006). Behavioral integration directly influences how top management teams deals with contradictory knowledge processes that support the accomplishment of an exploitation and exploratory orientation, such that the greater the integration greater is the realization of both (Lubatkin, et al., 2006; Simsek, 2009). Extending the work of Lubatkin et al. (2006), Simsek (2009) reasoned that top management teams play a fundamental role in modifying the impact of network centrality and multiplexity on ambidexterity. The top management team when behaviorally integrated, the resultant synchronization of social and task processes associated with collaborative behavior, quality of information exchange and joint decision making among senior executives can promote a deeper understanding and utilization of exploratory and exploitive opportunities, provided by network centrality and multiplexity (Simsek, 2009). Additionally, it is expected that behavioral integration will enable an organization to better manage diverse information and resource benefits associated with centrality and multiplexity (Simsek, 2009). Thus we posit:

Proposition 5e: The top management team within firms positively moderates the relationship between external networks Absorptive Capacity and Ambidexterity through centrality and multiplexity on ambidexterity.

Firms focusing on acquisition and assimilation of new external knowledge (i.e., potential absorptive capacity) are able to continually renew their knowledge stock, but they may suffer from the costs of acquisition without gaining benefits from exploitation (Zahra \& George, 2002). Conversely, firms focusing on transformation and exploitation (realized absorptive capacity) may achieve short-term profits through exploitation but fall into a competence trap (Ahuja \& Lampert, 2001; Zahra \& George, 2002)) and may not be able to respond to environmental changes. Realized absorptive capacity is likely to influence performance through product and process innovation (Jansen, et al., 2005b; Zahra \& George, 2002). Transformation, for instance, facilitates the combination of knowledge and the development of new perceptual schemas and proposals for changes to existing products, processes, and technologies (Jansen, et al. 2005). In addition, exploitation underlying a unit's realized absorptive capacity converts knowledge into products, services, and technologies. In this way, a firm's realized absorptive capacity is vital to a unit's innovation process and contributes to both exploratory and exploitative innovations (Jansen, et al., 2005b; Zahra \& George, 2002).

Transformation and exploitation processes may be aimed at deepening existing knowledge and skills, and improving efficiency (Jansen, et al., 2005b). In this way, realized absorptive capacity helps organizational units to create refinements to existing processes (Zahra \& George, 2002)and to reduce associated costs (Jansen, et al., 2005b). Additionally, realized absorptive capacity may also be aimed at developing and applying newly acquired external knowledge to pursue exploratory innovations (Jansen, et al., 2005b). Exploratory innovations originate from combining and interpreting existing and newly acquired external knowledge in a different manner (R. M. Henderson \& Clark, 1990; Kogut \& Zander, 1992). Thus, one can argue that realized absorptive capacity is positively associated with its exploitative as well as exploratory innovation. The balance between exploration and exploitation is ambidexterity which leads us to posit:

Proposition 6a: Realized absorptive capacity, through its ability to transformation and exploitation of external knowledge positively affects ambidexterity. 
Potential absorptive capacity becomes critical to renew a firm's knowledge stock, and develop innovative outcomes that differ substantially from existing products, services, and technologies (Jansen, et al., 2005b). Explorative innovations are radical innovations that place a sizeable premium on assimilative ability of new external knowledge (R. M. Henderson \& Clark, 1990; Jansen, et al., 2005b). Assimilative ability of external knowledge is an attribute of potential absorptive capacity (Zahra \& George, 2002). Because exploratory innovations require new knowledge or departure from existing knowledge (Levinthal \& March, 1993; McGrath, 2001), the acquisition and assimilation of new external knowledge contributes to a firm's ability to pursue exploratory innovations (Jansen, et al., 2005b). Conversely, without applying newly acquired and assimilated new external knowledge, organizational units are not able to pursue exploratory innovations successfully (Jansen, et al., 2005b). Thus a firm's potential absorptive capacity positively moderates the impact of realized absorptive capacity on exploratory innovations. However, potential absorptive capacity may hinder the efficient transformation and exploitation of knowledge (Jansen, et al., 2005b).

Speaking differently, organizations when increase their potential absorptive capacity, decrease the impact of realized absorptive capacity on exploitative innovations. From an intraorganizational standpoint, the aspects of top management teams, behavioral context and organizational structure that increases potential absorptive capacity, runs counter to realized-absorptive capacity. To increase potential absorptive capacity organization needs low formalization and high diverse networks, with moderate centrality, whereas for realized absorptive capacity one needs diverse networks under the lens of high formalization with high centrality. Thus, resources for acquisition and assimilation of new knowledge (for exploration) are different for exploitive innovations where one needs resources for with improvements to existing products, services, and technologies. In this sense, organizations that increase their potential absorptive capacity may hinder organizational tasks or operations to efficiently develop exploitative innovations (Jansen, et al., 2005b). Therefore, we propose:

Proposition 6b: Potential absorptive capacity moderates the relationship between realized absorptive capacity and ambidexterity. Such that, potential absorptive capacity positively and negatively moderates the relation between realized absorptive capacity on exploration and exploitation, respectively.

\section{Contributions}

\subsection{Theoretical and Practical Implications}

In this paper we introduced three antecedents to commercialization of Innovations (CI): networks, absorptive capacity and ambidexterity. We then expanded our discussion to see how these three antecedents are "inextricably linked" in an interplay model. Past works on these four constructs have prospered individually and at times concentrated on two of the three aspects, leaving room for discussions and curiosity to see how they affect each other. In the simplest terms, central to commercialization of innovation is a firm's ability to explore newer frontier and emerging markets while not destroying traditional and established markets: a balance termed as ambidexterity. To explore newer frontiers firms should be able to increase its capacity to absorb and assimilate new information, that is increase its absorptive capacity. Sources of new competencies, technologies are often outside the firm's existing boundaries. So external networks become imperative in expanding knowledge, which is complimentary to the firms existing stock. However, external networks may cripple a firm with information overload, and success often times lie in the firm's ability to develop and routinize information filters, internally. Thus, CI, ambidexterity, absorptive capacity and networks are inextricably linked, their relations are far from simple, rather quite equivocal, as depicted in the theoretical model. We believe an integral view will help us a more comprehensive understanding on the antecedents of CI and their interplay with each other. This is particularly important since there is a continued theoretical interest in CI, whereby the assumptions and boundary conditions need to be assessed, and the interplay between the antecedents and moderators need to be evaluated.

From a theoretical standpoint, this paper advances our understanding of the various facets of networks, and absorptive capacity and ambidexterity that lead to CI. In fact, while all these factors do explain, CI, they are very much dependent on each other. Although CI is the central construct of this paper, yet our discussions on the relationships other three constructs helped us getting a more comprehensive view. This work merges the gap between three constructs of interests whereby research in each area can enrich themselves by incorporating concepts from each other.

While, there has been disjoint attempts to integrate networks with absorptive capacity, networks with ambidexterity, and absorptive capacity with ambidexterity, this work opens door to include all three dimensions of organizational renewal. Research on networks can see increase in absorptive capacity and attainment exploration of emerging markets and technologies as a positive outcome. This study also extends our understanding of knowledge transfer through integration of complimentary knowledge and technologies, especially absorptive capacity and relative absorptive capacity (W. M. Cohen \& D. A. Levinthal, 1990; Lane \& Lubatkin, 1998). Research on relative absorptive suggests that a firm's ability to learn from its partner in a network is positively affected by similarity in their knowledge bases and structures. The 
construct of relative absorptive capacity should be expanded to include complimentarily of firm's knowledge bases (Makri, Hitt, \& Lane, 2010). Future research on absorptive capacity can use ambidexterity as context to see how relative absorptive capacity gets affected when technologies are distinct and the entities involved in the network are from different industries. We are confident that this model can pave way for new research by adding more comprehensive dimensions to view the outcome.

There are a number of practical lessons that this line of research can potentially offer to those managing firms. For example, this model suggests that for a firm to remain competitive in a globally competitive environment it must do a number of things well. First, the firm must create an environment that fosters knowledge sharing and diffusion through deployment of a number of internal mechanisms. Second, the firm must forge alliances with external partners to direct resources towards commercialization of innovations. Both these activities will lead to its ability to increase its absorptive capacity and ability to explore new areas and exploit current opportunities. Third, firms must be serious about forging alliances with academics and research organizations that do fundamental research and leveraging these relationships in ways that enable them to increase their potential and realized absorptive capacity and ambidexterity.

\subsection{Limitations and Future Research}

All work has limitations. In this work we treated ambidexterity and absorptive capacity as two distinctive constructs with no overlap. Although we have identified the causal relationships between the two constructs, but for matter of theoretical simplicity we are treating them as distinct. Further, we had limited the role of internal networks to moderate the relationship that external networks has with ambidexterity and CI. There can be a direct causality between internal networks with CI and ambidexterity. Such theoretical clarity can only arise when backed up by empirical evidence. In underscoring the relationship between external networks and absorptive capacity, we held internal networks constant, and vice versa. Also, we have not explained the relationship between internal and external networks. Although treated independently, it will be worth examining whether heterogeneity or centrality has an impact of internal organization of the firm. As of now it remained outside the scope of our theoretical model. Future research could look into the roles internal networks explicitly play toward CI and how external and internal networks relate to each other.

Lastly, in presenting our model we have assumed that the operating environment in terms of turbulence, complexity and dynamism remained constant. Future research should be geared towards - (a) effect of internal and external networks on absorptive capacities in each others' confluence, rather than independence, (b) direct effect of internal networks on ambidexterity and CI, (c) effect of operating environment on the posited relationships, and (d) construct overlap between ambidexterity and

Before these or any other lessons can be acted upon with confidence, much research remains to be done and we hope that this work sets forth a useful path for research in this area. Further, this paper opens the opportunity for research in both positivist and interpretivist paradigms. Surveys or secondary data sets could be used to conduct positivist research in order to test the propositions, while detailed case studies of specific firms in specific industries under certain circumstances may aid in attaining an interpretivist understanding of commercialization of innovation within firms in situ. Detailed studies could also be conducted in order to test specific relations between constructs.

\section{References}

Abernathy, W. J., \& Utterback, J. M. (1978). Patterns of industrial innovation. Technology Review, 80(7), 40-47.

Abrahamson, E., \& Rosenkopf, L. (1993). Institutional and competitive bandwagons: Using mathematical modeling as a tool to explore innovation diffusion. Academy of Management Review, 18(3), 487-517.

Agarwal, A. (2006). Engaging the inventor: Exploring licensing strategies for university inventions and the role of latent knowledge. Strategic Management Journal 27, 63-79.

Ahuja, G. (2000a). Collaboration Networks, Structural Holes, and Innovation: A Longitudinal Study. Administrative Science Quarterly, 45(3), 425-455.

Ahuja, G. (2000b). The duality of collaboration: Inducements and opportunities in the formation of interfirm linkages. Strategic Management Journal, 21(3), 317-343.

Ahuja, G., \& Katila, R. (2001). Technological acquisitions and the innovation performance of acquiring firms: a longitudinal study. Strategic Management Journal, 22(3), 197-220.

Ahuja, G., \& Lampert, C. M. (2001). Entrepreneurship in the large corporation: A longitudinal study of how established firms create breakthrough inventions. Strategic Management Journal, 22(6/7), 521-543. 
Alavi, M., \& Leidner, D. E. (2001). Knowledge management and knowledge management systems: Conceptual foundations and research issues. MIS Quarterly, 25(1), 107-136.

Anderson, M. H. (2008). Social networks and the cognitive motivation to realize network opportunities: A study of managers' information gathering behaviors. Journal of Organizational Behavior, 29(1), 51-78.

Andrew, J. P., \& Sirkin, H. L. (2003). Innovating for cash. Harvard Business Review, 81(9), 76-83.

Ariño, A., \& Reuer, J. J. (2006). Strategic alliances: Governance and contracts. New York: Palgrave Macmillan.

Bantel, K. A., \& Jackson, S. E. (1989). Top management and innovations in banking: Does the composition of the top team make a difference? Strategic Management Journal, 10(Summer), 107-124.

Barney, J. B. (1991). Firm resources and sustained competitive advantage. Journal of Management, 17(1), 99-120.

Barringer, B., \& Harrison, J. (2000). Walking a tightrope: Creating value through interorganizational relationships. Journal of Management, 26(3), 367-403.

Baum, J. A. C., Calabrese, T., \& Silverman, B., S. (2000). Don't go it alone: Alliance network composition and startups' performance in Canadian biotechnology. Strategic Management Journal, 21(3), 267-294.

Beckman, C. M., \& Haunschild, P. R. (2002). Network learning: The effects of partners' heterogeneity of experience on corporate acquisitions. Administrative Science Quarterly, 47(1), 92-124.

Bell, G., G. (2005). Clusters, networks, and firm innovativeness. Strategic Management Journal, 26(3), $287-295$.

Benner, M. J., \& Tushman, M. L. (2003). Exploitation, exploration, and process management: The productivity dilemma revisited. Academy of Management Review, 28(2), 238-256.

Birkinshaw, J., \& Gibson, C. (2004). Building ambidexterity into an organization. Sloan Management Review, 45(4), 46-55

Bodwell, W., \& Chermack, T. J. (2009). Organizational ambidexterity: Integrating deliberate and emergent strategy with scenario planning. Technological Forecasting and Social Change, 77(2), 193-202.

Borgatti, S. P. (2005). Centrality and network flow. Social Networks, 27(1), 55-71.

Borgatti, S. P., \& Everett, M. G. (2006). A graph-theoretic perspective on centrality. Social Networks, 28(4), $466-484$.

Brass, D. J., Galaskiewicz, J., \& Greve, H. R. (2004). Taking stock of networks and organizations: A multilevel perspective. Academy of Management Journal, 47(6), 795-817.

Brikinshaw, J., \& Gibson, C. (2004). Building Ambidexterity into an organization. Sloan Management Review, 45(4), 46-55

Burgelman, R. A. (2002). Strategy as vector and the inertia of coevolutionary lock-in. Administrative Science Quarterly, 47(2), 325-357.

Burgelman, R. A., Christensen, C. M., \& Wheelright., S. C. (2006). Strategic management of technology and innovation. New York: McGraw Hill Irwin.

Burgelman, R. A., \& Grove, A. S. (1996). Strategic dissonance. California Management Review, 38(2), 8-28.

Burns, L. R., \& Wholey, D. R. (1993). Adoption and abandonment of matrix management programs: Effects of organizational characteristics and interorganizational networks. Academy of Management Journal, 36(1), 106-138.

Burt, R. S. ( 1992). Structural holes: The social structure of competition. Cambridge, MA: Harvard University Press.

Chataway, J., \& Wield, J. (2000). Industrialization, innovation and development: What does knowledge management change? Journal of International Development, 12(6), 803-824.

Chen, C. J. (2004). The effects of knowledge attribute, alliance characteristics, and absorptive capacity on knowledge transfer performance. R\&D Management, 34(3), 311-321.

Christensen, C. M. (1992a). Exploring the limits of the technology s-curve. Part I: Component technologies. Production and Operations Management, 1(4), 334-357.

Christensen, C. M. (1992b). Exploring the limits of the technology s-curve. Part II: Architectural technologies. Production and Operations Management, 1(4), 358-366.

Clark, K. B., \& Fujimoto, T. (1987). Overlapping problem-solving in product development. Cambridge, MA: Harvard University Press. 
Cohen, L. Y., Kamienski, P. W., \& Espino, R. L. (1998). Gate System Focuses Industrial Basic Research. Research Technology Management, 41(4), 34-37.

Cohen, W. M., Florida, R., Randazzes, L., \& Walsh, J. (1998). Industry and the academy: Uneasy partners in the cause of technological advance. In R. Noll (Ed.), Challenges to Research Universities (pp. 171-200). Washington, DC: The Brookings Institution.

Cohen, W. M., Goto, A., Nagata, A., Nelson, R. R., \& Walsh, J. P. (2002). R\&D spillovers, patents and the incentives to innovate in Japan and the United States. Research Policy, 31, 1349-1367.

Cohen, W. M., \& Levinthal, D. (1990). Absorptive capacity: A new perspective on learning and innovation. Administrative Science Quarterly 35(1), 128-152.

Cohen, W. M., \& Levinthal, D. A. (1990). Absorptive Capacity: A New Perspective on Learning and Innovation. Administrative Science Quarterly, 35(1), 128-152.

Cohen, W. M., Nelson, R. R., \& Walsh, J. P. (2002). Links and impacts: The influence of public research on industrial R\&D. Management Science, 48(1), 1-23.

Collin, J. C., \& Porras, J. I. (1997). Built to last: Successful habits of visionary companies. New York: Harper Business.

Collin, J. C., \& Porras, J. I. (1999). Built to Last. Successful habits of visionary companies: Random house business Books.

Colyvas, J., Crow, M., Gelijns, A., Mazzoleni, R., Nelson, R. R., Rosenberg, N., \& Sampat, B. N. (2002). How do university inventions get into practice? Management Science, 48(1), 61-72.

Damanpour, F. (1991). Organizational innovation: A meta-analysis of effects of determinants and moderators. Academy of Management Journal, 34, 555-590

Datta, A. (2011a). An Integrative Model to Explain the Ability to Commercialize Innovations: Linking Networks, Absorptive Capacity, Ambidexterity and Environmental Factors. . Journal of Management \& Strategy, 2(2), 2-22.

Datta, A. (2011b). Review and Extension on Ambidexterity: A Theoretical Model Integrating Networks and Absorptive Capacity. Journal of Management \& Strategy, 2(1), 2-22.

Datta, A., \& Jessup, L. (2009). Expanding Opportunities in a Shrinking World: A Conceptual Model Explicating the Role of Social Networks and Internet-Based Virtual Environments in Social Entrepreneurship. International Journal of Virtual Communities and Social Networking, 1(4), 33-49.

Dess, G. G., \& Beard, D. W. (1984). Dimensions of organizational task environments. Administrative Science Quarterly, 29(1), 52-73.

Dougerty, D., \& Hardy, C. (1996). Sustained product innovation in large mature organizations: Overcoming innovation-to-organization problems. Academy of Management Journal, 39(5), 1120-1153

Drucker, P. (1985). Innovation and entrepreneurship: Practice and principles. New York: Harper and Row.

Duncan, R. B. (1976). The ambidextrous organization: Designing dual structures for innovation. The Management of Organization: Strategy and Implementation, 1, 167-188.

Dyer, J. H., \& Singh, H. (1998). The relational view: Cooperative strategy and sources of interorganizational competitive advantage. Academy of Management Review, 23(4), 660-679.

Eisenhardt, K. M. (2000). Paradox, Spirals, Ambivalence: The New Language of Change and Pluralism. Academy of Management Review, 25(4), 703-705

Ellis, C. (2003). The Flattening corporation. Sloan Management Review, 44(4), 5.

Freeman, C. (1991). Networks of innovators: A synthesis of research issues. Research Policy, 20(5), 499-514.

Freeman, L. C. (1977). A set of measures of centrality based on betweenness. Sociometry, 40(1), 35-41.

Freeman, L. C. (1979). Centrality in social networks: conceptual clarification. Social Networks, 1(3), 215-239.

Freeman, L. C. (1980). The gatekeeper, pair-dependency, and structural centrality. Quality and Quantity 14(4), 585-592.

Galunic, D. C., \& Eisenhardt, K. M. (1996). The evolution of intracorporate domains: Divisional charter losses in high-technology, multidivisional corporations. Organization Science, 7(3), 255-282.

Gersick, C. J. G. (1991). Revolutionary change theories: A multilevel exploration of the punctuated equilibrium paradigm. Academy of Management Review, 16(1), 10-36. 
Gibson, C. B., \& Birkinshaw, J. (2004). The antecedents, consequences, and mediating: Role of organizational ambidexterity. Academy of Management Journal, 47(2), 209-226.

Gnyawali, D. R., He, J., \& Madhvan, R. (2006). Impact of co-opetition on firm competitive behavior: An empirical Analysis. Journal of Management, 32(4), 507-530.

Grant, R. M. (1996). Prospering in Dynamically-Competitive Environments: Organizational Capability as Knowledge Integration. Organization Science, 7(4), 375-387.

Grove, A. S. (1996). Only the paranoid survives: Exploit the crisis point that challenge every company and career. New York: Doubleday Dell Publishing Group, Inc.

Gulati, R. (1995). Social Structure and Alliance Formation Patterns: A Longitudinal Analysis Administrative Science Quarterly 40(4), 619-652

Gulati, R. (1998). Alliances and networks. Strategic Management Journal, 19(4), 293-317.

Gulati, R., \& Gargiulo, M. (1999). Where do interorganizational networks come from? . American Journal of Sociology, 104(5), 1439-1493.

Gulati, R., \& Kletter, D. (2005). Shrinking core, expanding periphery: The relational architecture of high performing organizations. California Management Review, 47(3), 77-104.

Gulati, R., Nohria, N., \& Zaheer, A. (2000). Strategic networks. Strategic Management Journal, 21(3), $203-215$.

Gupta, A. K., Tesluk, P. E., \& Taylor, S. M. (2007). Innovation at and across multiple levels of analysis. Organization Science, 18(6), 889-897.

Hansen, M. T., \& Birkinshaw, J. (2007). The innovation value chain. Harvard Business Review, 85(6), 121-130.

He, Z.-L., \& Wong, P.-K. (2004). Exploration vs. Exploitation: An Empirical Test of the Ambidexterity Hypothesis. Organization Science, 15(4), 481-494.

Henderson, R., \& Cockburn, I. (1996). Scale, scope, and spillovers: The determinants of research productivity in drug discovery. The RAND Journal of Economics, 27(1), 32-59.

Henderson, R., Jaffe, A. B., \& Trajtenberg, M. (1998). Universities as a source of commercial technology: A detailed analysis of university patenting, 1965 -1988. Review of Economics and Statistics, 80(1), 119-127. doi: doi:10.1162/003465398557221

Henderson, R. M., \& Clark, K. B. (1990). Architectural innovation: The reconfiguration of existing product technologies and the failure of established firms. Administrative Science Quarterly, 35(1), 9-30.

Hill, S. A., \& Birkinshaw, J. (2006). Ambidexterity in corporate venturing: Simultaneously using existing and building new capabilities. Paper presented at the Academy of Management Meeting, Atlanta, GA.

Hoegl, M., \& Schulze, A. (2005). How to support knowledge creation in new product development: An investigation of knowledge management methods. European Management Journal, 23(3), 263-273.

Howell, J. M., \& Higgins, C. A. (1990). Champions of technological innovation. Administrative Science Quarterly, 35(2), 317-341.

Huygens, M., Van Den Bosh, F. A. J., Volberda, H. W., \& Baden-Fuller, C. (2001). Co-evolution of firm capabilities and industry competition: Investigating the music Industry. Organization Studies, 22(6), 791-1011.

Jaffe, A. B., Trajtenberg, M., \& Henderson, R. (1993). Geographic localization of knowledge spillovers as evidenced by patent citations. The Quarterly Journal of Economics, 108(3), 577-598.

Jansen, J. (2005). Ambidextrous organizations: A multiple-level study of absorptive capacity, exploratory and exploitative innovation, and performance. Unpublished Dissertation. Unpublished doctoral dissertation. Erasmus Research Institute of Management, Erasmus University. Rotterdam.

Jansen, J., Vanden Bosch, F. A. J., \& Volberda, H. W. (2005a). Exploratory innovation, exploitive innovation and ambidexterity: The impact of environmental and organizational antecedents. Schmalenbach Business Review, 57, 351-363.

Jansen, J., Vanden Bosch, F. A. J., \& Volberda, H. W. (2005b). Managing potential and realized absorptive capacity: How do organizational antecedents matter? . Academy of Management Journal, 48(5), 999-1015. 
Jansen, J., Vanden Bosch, F. A. J., \& Volberda, H. W. (2006). Exploratory innovation, exploitive innovation and performance: Effects of organizational antecedents and environmental moderators. Management Science, 52(11), 1661-1674.

Katila, R., \& Ahuja, G. (2002). Something Old, Something New: A Longitudinal Study of Search Behavior and New Product Introduction. Academy of Management Journal, 45(6), 1183-1194.

Keats, B., \& Hitt, M. A. (1988). A causal model of linkages among environmental dimensions, macro organizational characteristics, and performance. Academy of Management Journal, 31(3), 570-598.

Kelm, K. M., Narayanan, V. K., \& Pinches, G. E. (1995). Shareholder value creation during R\&D innovation and commercialization stages. Academy of Management Journal, 38(3), 770-786.

Kirzner, I. M. (1997). Entrepreneurial discovery and the competitive market process: An Austrian approach. Journal of Economic Literature, 35(1), 60-85.

Klein, R., Rai, A., \& Straub, D. W. (2007). Competitive and Cooperative Positioning in Supply Chain Logistics Relationships. Decision Sciences, 38(4), 611-646.

Klein, R., Rai, A., \& Straub, D. W. (2007). Competitive and Cooperative Positioning in supply chain Logistics Relationships. Decision Sciences, 38(4), 1-38.

Kogut, B., \& Zander, U. (1992). Knowledge of the firm, combinative capabilities, and the replication of technology. Organization Science, 3(3), 383-397.

Koka, B. R., \& Prescott, J. E. (2002). Strategic alliances as social capital: a multidimensional view. Strategic Management Journal, 23(9), 795-816.

Kwak, M. (2002). What's the best commercialization strategy for startups? . Sloan Management Review, $48(3), 10$.

Lane, P. J., Koka, B. R., \& Pathak, S. (2006). The Reification of Absorptive Capacity: A Critical Review and Rejuvenation of the Construct. Academy of Management Review, 31(4), 833-863

Lane, P. J., \& Lubatkin, M. (1998). Relative absorptive capacity and interorganizational learning. Strategic Management Journal, 19(5), 461-477.

Lane, P. J., Salk, J. E., \& Lyles, M. A. (2001). Absorptive capacity, learning, and performance in international joint ventures. Strategic Management Journal, 22(12), 1139-1161.

Lavie, D., \& Rosenkopf, L. (2006). Balancing exploration and exploitation in alliance formation. Academy of Management Journal, 49(4), 797-818.

Levinthal, D. A. (1997). Adaptation on rugged landscapes. Management Science, 43(7), 934-950.

Levinthal, D. A., \& March, J. G. (1993). The myopia of learning. Strategic Management Journal, 14, 95-112.

Lewin, A. Y., \& Volberda, H. W. (1999). Prolegomena on coevolution: A framework for research on strategy and new organizational forms. Organization Science, 10(5), 519-534.

Lewis, M. W. (2000). Exploring Paradox: Toward a More Comprehensive Guide. The Academy of Management Review, 25(4), 760-776.

Lubatkin, M. H., Simsek, Z., \& Veiga, J. F. (2006). Ambidexterity and performance in small- to medium-sized firms: The pivotal role of top management team behavioral integration. Journal of Management, 32(5), 646-672.

Makri, M., Hitt, M., \& Lane, P. (2010). Complementary technologies, knowledge relatedness, and invention outcomes in high technology mergers and acquisitions. Strategic Management Journal, 31(6), 602-628.

March, J. G. (1991). Exploration and exploitation in organizational learning. Organization Science 2(1), 71-87.

Mata, F. J., Fuerst, W. L., \& Barney, J. B. (1995). Information technology and sustained competitive advantage: A resource-based analysis. MIS Quarterly, 19(4), 487-505.

McGrath, R. G. (2001). Exploratory learning, innovative capacity and managerial oversight. The Academy of Management Journal, 44(1), 118-131.

McGrath, R. G., Tsai, M.-H., Venkataraman, S., \& MacMillan, I. C. (1996). Innovation, competitive advantage and rent: A model and test. Management Science, 42(3), 389-403.

Melville, N., Kraemer, K. L., \& Gurbaxani, V. (2004). Information technology and organizational performance: An integrative model of IT-business value. MIS Quarterly, 28(2), 283-322. 
Milliken, F. J. (1987). Three types of perceived uncertainty about the environment: State, effect, and response uncertainty. Academy of Management Review, 12(1), 133-143.

Mitchell, W. (1989). Whether and when? Probability and timing of incumbents' entry into emerging industrial subfields. Administrative Science Quarterly, 34(2), 208-230.

Moore, G. A. (1991). Crossing the chasm. Marketing and selling disruptive products to mainstream customers. New-York: Harper Business.

Moore, G. A. (2000). Living on the fault line. Managing for shareholder value in the age of the Internet. New York: Harper Business.

Nahapiet, J., \& Ghoshal, S. (1998). Social capital, intellectual capital, and the organizational advantage. Academy of Management Review, 23(2), 242-266.

Nambisan, S., \& Sawhney, M. (2007). A buyer's guide to the Innovation Bazar. Harvard Business Review, 85(6).

Narasimhan, O., Rajiv, S., \& Dutta, S. (2006). Absorptive Capacity in High-Technology Markets: The Competitive Advantage of the Haves. MARKETING SCIENCE, 25(5), 510-524. doi: 10.1287/mksc.1060.0219

Narayanan, V. K., Pinches, G. E., Kelm, K. M., \& Lander, D. M. (2000). The influence of voluntarily disclosed qualitative information. Strategic Management Journal, 21(7), 707-722.

Nerkar, A., \& Shane, S. (2007). Determinants of invention commercialization: An empirical examination of academically sourced inventions. Strategic Management Journal, 28(11), 1155-1166.

Nerkar, A. A., McGrath, R. G., \& MacMillan, I. C. (1996). Three facets of satisfaction and their influence on the performance of innovation teams. Journal of Business Venturing, 11(3), 167-188.

Nevens, T. M., Summe, G. L., \& Uttal, B. (1990). Commercializing technology: What do the best companies do? Harvard Business Review on Entrepreneurship (Vol. 1999, pp. 175). Cambridge, MA: Harvard Business School Press.

Newell, S., \& Clark, P. (1990). The importance of extra-organizational networks in the diffusion and appropriation of new technologies. Science Communication, 12(2), 199-212.

Newman, M. E. J. (2001). Scientific collaboration networks. II. Shortest paths, weighted networks, and centrality. Physical Review, 64(1), 1-7.

Newman, M. E. J. (2005). A measure of betweenness centrality based on random walks. Social Networks, 27(1), 39-54.

Nohria, N. (1992). Is a network perspective a useful way of studying organizations? In N. Nohria \& R. G. Eccles (Eds.), Networks and Organization: 287-301 Cambridge, MA: Harvard Business School Press.

Nohria, N., \& Eccles, R. G. (1992). Networks and organizations: Structure, form, and action. Cambridge, MA: Harvard Business School Press.

Numprasertchai, S., \& Igel, B. (2005). Managing knowledge through collaboration: Multiple case studies of managing research in university laboratories in Thailand. Technovation, 25(10), 1173-1182.

O'Reilly, C. A., III, \& Tushman, M. (2007). Ambidexterity as a Dynamic Capability: Resolving the Innovator's Dilemma. Stanford University Graduate School of Business Research Paper No. 1963.

O’Reilly, C. A., \& Tushman, M. L. (2004). Ambidextrous organization. Harvard Business Review 82(4), 71-81.

Ocasio, W. (1997). Towards an Attention-Based View of the Firm. Strategic Management Journal, 18(1), $187-206$.

Oliver, A. L. (2004). Biotechnology entrepreneurial scientists and their collaborations. Research Policy, 33(4), $583-597$.

Pennings, J. M., \& Harianto, F. (1992). Technological networking and innovation implementation. Organization Science, 3(3), 356-382.

Pfeffer, J., \& Salancik, G. R. (1978). The external control of organizations: A resource dependence perspective. New York: Harper \& Row.

Phelps, C. (2003). Technological exploration: A longitudinal study of the role of recombinatory search and social capital in alliance networks. Unpublished dissertation. Unpublished dissertation. New York University. New York.

Phelps, C. (2010). A longitudinal study of the influence of alliance network structure and composition on firm exploratory innovation. Academy of Management Journal, 53(4), 890-913.

Porter, M. E. (1980). Competitive Strategy. New York: Free Press. 
Porter, M. E. (1998). Cluster and Competition: New agendas for firms, governments, and institutions. In M. E. Porter (Ed.), Michael Porter on competition: 213-308. Cambridge, MA: Harvard Business School Press.

Powell, W. W. (1998). Learning from collaboration: Knowledge and networks in the biotechnology and pharmaceutical industries. California Management Review, 40(3), 228-240.

Powell, W. W., Koput, K. W., \& Smith-Doerr, L. (1996). Interorganizational Collaboration and the Locus of Innovation: Networks of Learning in Biotechnology. Administrative Science Quarterly, 41(1), 116-145.

Provan, K. G., Fish, A., \& Sydow, J. (2007). Interorganizational networks at the network level: A review of empirical literature on whole networks. Journal of Management, 33(3), 479-516.

Raisch, S., \& Birkinshaw, J. (2008). Organizational ambidexterity: Antecedents outcomes and moderators. Journal of Management, 34(3), 275-409.

Ray, G., Muhanna, W., \& Barney, J. B. (2005). Information technology and the performance of the customer service process: A resource-based analysis. MIS Quarterly, 29(4), 625-652.

Rothaermel, F. T., \& Thursby, M. (2005). University-incubator firm knowledge flows: Assessing their impact on incubator firm performance. Research Policy, 34(3), 305-320.

Salman, N., \& Saives, A.-L. (2005). Indirect networks: An intangible resource for biotechnology innovation. $R \& D$ Management, 35(2), 203-215.

Schilling, M. A., \& Phelps, C. C. (2007). Interfirm Collaboration Networks: The Impact of Large-Scale Network Structure on Firm Innovation. Management Science, 53(7), 1113-1126. doi: 10.1287/mnsc.1060.0624

Scott, J. (1991). Social Network Analysis: A Handbook. Thousand Oaks, CA: Sage.

Scott, S. G., \& Bruce, R. A. (1994). Determinants of innovative behavior: A path model of individual innovation in the workplace. The Academy of Management Journal, 37(3), 580-607.

Seppanen, V., \& Skates, M. (2001). Managing relationships and competence to stay market oriented: The case of a Finnish contract research organization. Paper presented at the American Marketing Association. Conference Proceedings.

Shane, S. (2000). Prior knowledge and the discovery of entrepreneurial opportunities. Organization Science, 11(4), 448-469.

Sidhu, J., S, Commandeur, H., R, \& Volberda, H. W. (2007). The multifaceted nature of exploration and exploitation: Value of supply, demand, and spatial search for innovation. Organization Science, 18(1), 20-38.

Sidhu, J., S, Volberda, H. W., \& Commandeur, H., R. (2004). Exploring exploration orientation and its determinants: Some empirical evidence. Journal of Management Studies, 41(6), 913-932.

Siggelkow, N., \& Levinthal, D. A. (2003). Temporarily Divide to Conquer: Centralized, Decentralized, and Reintegrated Organizational Approaches to Exploration and Adaptation. Organization Science, 14(6), 650-669. doi: 10.1287/orsc. 14.6.650.24840

Simsek, Z. (2009). Organizational ambidexterity: Towards a multilevel understanding. Journal of Management Studies, 46(4), 597-624.

Simsek, Z., Heavey, C., Veiga, J. F., \& Souder, D. (2009). A Typology for Aligning Organizational Ambidexterity's Conceptualizations, Antecedents, and Outcomes. Journal of Management Studies, 46(5), 864-894.

Smith, W. K., \& Tushman, M. L. (2005). Managing Strategic Contradictions: A Top Management Model for Managing Innovation Streams. Organization Science, 16(5), 522-536. doi: 10.1287/orsc.1050.0134

Soh, P.-H. (2003). The role of networking alliances in information acquisition and its implications for new product performance. Journal of Business Venturing, 18(6), 727-744.

Teece, D. J. (1986). Profiting from technological innovation: Implication for integration, collaboration, licensing and public policy. Research Policy, 15(6), 285-305.

Teece, D. J., Pisano, G., \& Shuen, A. (1997). Dynamic capabilities and strategic management. Strategic Management Journal, 18(7), 509-533.

Todorova, G., \& Durisin, B. (2007). Absorptive Capacity: Valuing a reconceptualization. [Article]. Academy of Management Review, 32, 774-786. 
Tushman, M. L., \& O’Reilly, C. A. (1996a). Ambidextrous organizations: Managing evolutionary and revolutionary change. California Management Review, 38(4), 8-30.

Tushman, M. L., \& O’Reilly, C. A. (1996b). Ambidextrous organizations: Managing evolutionary and revolutionary change. California management Review, 38(4).

Tushman, M. L., \& O’Reilly, C. A. (2002). Winning through innovation: A practical guide to leading organizational change and renewal. Boston, MA: Harvard Business School Press.

Van den Bosch, F. A. J., Volberda, H. W., \& Boer, M. d. (1999). Coevolution of firm absorptive capacity and knowledge environment: Organizational forms and combinative capabilities. Organization Science, 10(5), 551-568.

Van Wijk, R. (2003). Organizing Knowledge in Internal Networks. ERIM PhD Series Research in Management, ISBN 90-5892-039-9. Erasmus Research Institute of Management, Erasmus University. Rotterdam.

Volberda, H. W. (1996). Toward the flexible form: How to remain vital in hypercompetitive environments. Organization Science, 7(4), 359-374.

Volberda, H. W., \& Lewin, A. Y. (2003). Co-evolutionary dynamics within and between firms: From evolution to co-evolution. Journal of Management Studies, 40(8), 2105-2130.

Wade, J. (1996). A community-level analysis of sources and rates of technological variation in the microprocessor market. The Academy of Management Journal, 39(5), 1218-1244.

Wade, M., \& Hulland, J. (2004). The resource based view and information systems research: Review, extension, suggestions for future research. MIS Quarterly, 28(1), 107-142.

Wasserman, S., \& Faust, K. (1994). Social network analysis: Methods and applications. Cambridge, UK: Cambridge University Press.

Wielemaker, M. (2003). Managing initiatives: A synthesis of the conditioning and knowledge-creating view. ERIM PhD Series Research in Management ISBN 90-5892-050-X. Erasmus University Rotterdam. Rotterdam.

Williamson, O. E. (1991). Comparative economic organization: The analysis of discrete structural alternatives. Administrative Science Quarterly, 36(2), 269-296.

Yli-Renko, H., Autio, E., \& Sapienza, H. J. (2001). Social Capital, Knowledge Acquisition, and Knowledge Exploitation in Young Technology-Based Firms. Strategic Management Journal, 22(6/7), 587-613.

Zack, M. H. (1999). Developing knowledge strategy. California management Review, 41, 125-145.

Zack, M. H. (2003). Rethinking knowledge based organization. Sloan Management Review, 44(4), 12-17.

Zahra, S. A., \& George, G. (2002). Absorptive capacity: A review, reconceptualization, and extension. Academy of Management Review, 27(2), 185-203.

\section{Notes}

Note 1. By entities we mean subunits within organizations, and with other firms. 


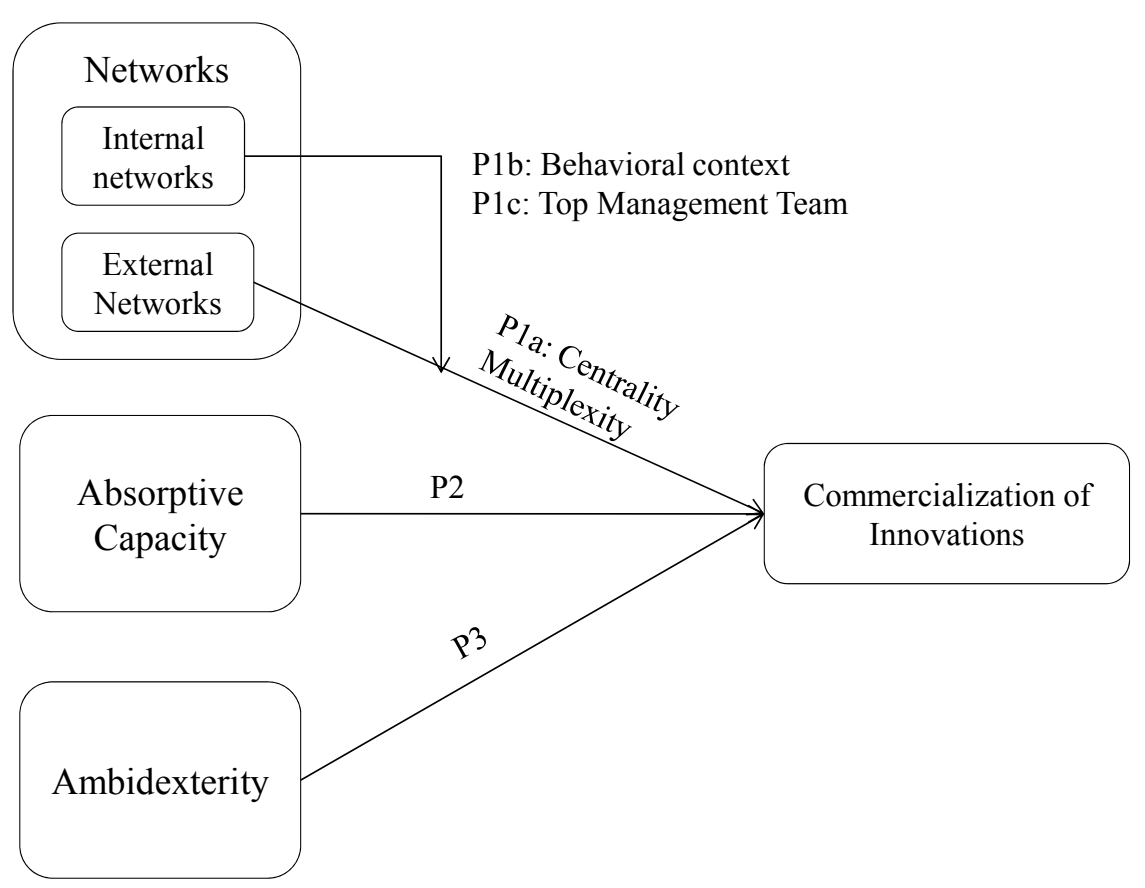

Figure 1. Baseline Model: Factors affecting commercialization of innovations

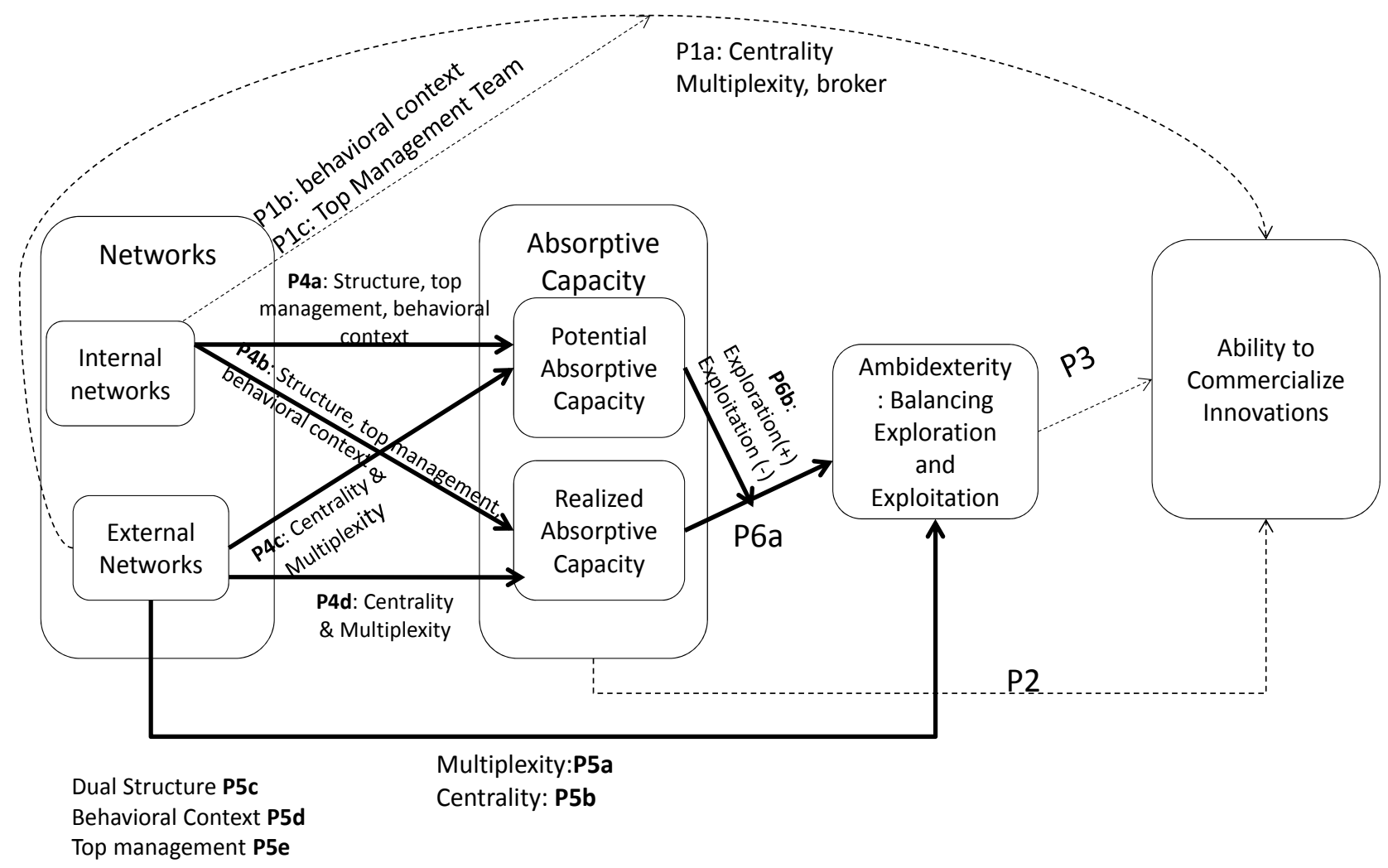

Figure 2: Interplay Model: Relationship among Networks, Absorptive Capacity and Ambidexterity. Base line Model with DV depicted in dotted lines 